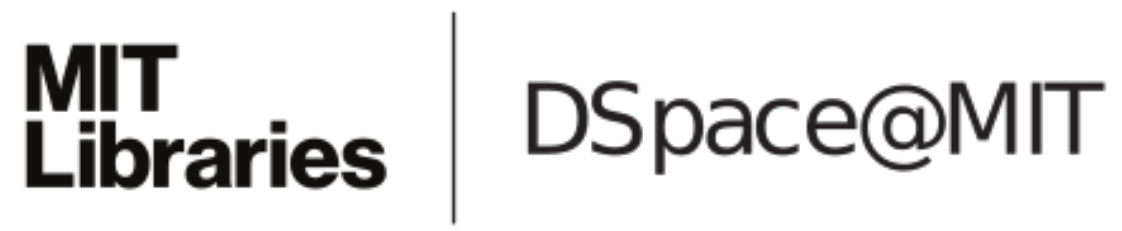

\author{
MIT Open Access Articles
}

Explaining Charter School Effectiveness

The MIT Faculty has made this article openly available. Please share how this access benefits you. Your story matters.

Citation: Angrist, Joshua D., Parag A. Pathak, and Christopher R. Walters. “Explaining Charter School Effectiveness." American Economic Journal: Applied Economics 5, no. 4 (October 2013): 1-27. (c) 2013 American Economic Association

As Published: http://dx.doi.org/10.1257/app.5.4.1

Publisher: American Economic Association

Persistent URL: http://hdl.handle.net/1721.1/96157

Version: Final published version: final published article, as it appeared in a journal, conference proceedings, or other formally published context

Terms of Use: Article is made available in accordance with the publisher's policy and may be subject to US copyright law. Please refer to the publisher's site for terms of use. 


\title{
Explaining Charter School Effectiveness
}

\author{
By Joshua D. Angrist, Parag A. Pathak, and Christopher R. Walters*
}

\begin{abstract}
Lottery estimates suggest Massachusetts'urban charter schools boost achievement well beyond that of traditional urban public schools students, while nonurban charters reduce achievement from a higher baseline. The fact that urban charters are most effective for poor nonwhites and low-baseline achievers contributes to, but does not fully explain, these differences. We therefore link school-level charter impacts to school inputs and practices. The relative efficacy of urban lottery sample charters is accounted for by these schools' embrace of the No Excuses approach to urban education. In our Massachusetts sample, Non-No-Excuses urban charters are no more effective than nonurban charters. (JEL H75, I21, I28)
\end{abstract}

\begin{abstract}
growing body of evidence suggests that urban charter schools have the potential to generate impressive achievement gains, especially for minority students living in high-poverty areas. In a series of studies using admissions lotteries to identify causal effects, we looked at the impact of charter attendance in Boston and at a Knowledge is Power Program (KIPP) school in Lynn, Massachusetts (Abdulkadiroğlu et al. 2009, 2011; Angrist et al. 2010, 2012). Boston and Lynn charter middle schools increase student achievement by about 0.4 standard deviations $(\sigma)$ per year in math and about $0.2 \sigma$ per year in English Language Arts (ELA). Among high school students, attendance at a Boston charter school increases student achievement by about $0.3 \sigma$ per year in math and $0.2 \sigma$ per year in ELA. Lottery studies of charter schools in the Harlem Children's Zone (Dobbie and Fryer 2011a) and a Washington, DC charter boarding school (Curto and Fryer 2011) find similarly large gains. Studies of Chicago and New York charter schools also report positive effects (Hoxby and Rockoff 2004; Hoxby, Murarka, and Kang 2009; Dobbie and Fryer 2011b).
\end{abstract}

\footnotetext{
*Angrist: Department of Economics, Massachusetts Institute of Technology and NBER, E52-393, 50 Memorial Drive, Cambridge, MA 02142 (e-mail: angrist@mit.edu); Pathak: Massachusetts Institute of Technology, E52391C, 50 Memorial Drive, Cambridge, MA 02142 (e-mail: ppathak@mit.edu); Walters: University of California, Berkeley, 530 Evans Hall \#3880, Berkeley, CA 94720 (e-mail: crwalters@econ.berkeley.edu). Special thanks go to Carrie Conaway, Sarah Cohodes, Jon Fullerton, Harvard's Center for Education Policy Research, and the Massachusetts Department of Education for assistance and data, and to our charter team collaborators, Sue Dynarski and Tom Kane for their valuable input. Seminar participants at Boston College, Columbia University, Harvard University, HEC Montreal, Miami Ohio, The University of Trento, The University of Virginia, Wharton School of Business, the Society for Research on Educational Effectiveness Spring 2012 conference in Washington, DC, and the August 2011 Impact Evaluation Network meeting in Buenos Aires provided extensive helpful comments. This work was funded by Institute for Education Sciences award number R305A120269 and the Massachusetts Department of Elementary and Secondary Education. Pathak gratefully acknowledges support from National Science Foundation grant SES-1056325. The views expressed here are those of the authors alone.

${ }^{\dagger}$ Go to http://dx.doi.org/10.1257/app.5.4.1 to visit the article page for additional materials and author disclosure statement $(\mathrm{s})$ or to comment in the online discussion forum.
} 
While these results are encouraging, they come from schools operating in traditional (for charters) urban settings. Interest in charter schools is growing rapidly in school districts outside central cities (see, e.g., Hu 2011), but results for more diverse sets of charter schools are also more mixed. In a recent report evaluating roughly two dozen Massachusetts charter schools from around the state, we find little evidence of achievement gains at schools outside of high-poverty urban areas (Angrist, Pathak, and Walters 2011). Some of the estimates for nonurban Massachusetts charters show significant negative effects. These results echo findings from a multi-state study of 36 charter middle schools using admissions lotteries (Gleason et al. 2010).11 Here too, charter schools outside of urban areas seem to do little for achievement, though, as in our earlier work, urban schools with high-minority, high-poverty enrollment generate some gains. ${ }^{2}$

This paper documents treatment effect heterogeneity in a large sample of Massachusetts charter schools and develops a framework for interpreting this heterogeneity using both student- and school-level explanatory variables. We begin with a semiparametric investigation of potential outcomes that assigns a role to variation in no-treatment counterfactuals and to charter applicants' demographic characteristics and baseline achievement. This investigation includes a Blinder (1973)-Oaxaca (1973) decomposition of the urban charter advantage. The resulting estimates show that students at urban charters are typical of the urban student population, and that urban charter attendance boosts achievement well beyond ambient noncharter levels. Student demographics and baseline scores play a role in this-urban schools are most effective for minority students and students with low baseline scores-but nonurban charters appear to be ineffective for most subgroups.

We then investigate school-level factors that might explain differences in charter school effectiveness. This investigation is built on a set of nonlottery estimates that rely on statistical controls to eliminate selection bias. The observational analysis suggests that the sample of urban schools for which a lottery-based analysis is feasible, that is, oversubscribed schools with good lottery records, boost scores more than other urban charter schools. We show that urban and lottery-sample charter effectiveness can be explained by adherence to a No Excuses approach to urban education that emphasizes discipline and comportment, traditional reading and math skills, instruction time, and selective teacher hiring. Using a detailed survey of school practices and characteristics, we document the practices most characteristic of No Excuses schools. Relative to other Massachusetts charter schools, No Excuses schools are more likely to feature strict discipline, uniforms, and cold-calling, to employ alumni of the Teach for America (TFA) program, and to videotape lessons for teacher feedback. Conditional on No Excuses status, traditional inputs, such as time in school and per-pupil expenditure, are not predictive of charter effectiveness.

\footnotetext{
${ }^{1}$ Other studies documenting heterogeneity in the effects of charter schools include Hoxby (2004), Zimmer et al. (2009), and Imberman (2011). The Imberman study reports that urban charter school start-ups have large effects on discipline and attendance, while converted schools do not.

${ }^{2} \mathrm{~A}$ focus on differences between urban and nonurban schools also appears in research on Catholic schools. Evans and Schwab (1995) and Neal (1997) show that Catholic school attendance leads to increases in high school graduation and college attendance for cohorts graduating in the early 1980s. Both studies find larger benefits for black students and for students in urban settings. Grogger and Neal (2000) and Altonji, Elder, and Taber (2005) report similar findings for more recent cohorts.
} 
The results reported here contribute to a growing body of evidence documenting the effectiveness of No Excuses practices in various contexts. Dobbie and Fryer (2011b) show that an index measuring teacher feedback, data-driven instruction, tutoring, increased instruction time, and high expectations is a significant predictor of effectiveness in a sample of New York charter schools. These practices are typically understood to be central elements of the No Excuses model (Thernstrom and Thernstrom 2003; Carter 2000), and are highly correlated with No Excuses status in our sample. Similarly, Fryer (2011) reports on an experiment implementing No Excuses strategies in nine low-performing traditional public schools in Houston. This intervention appears to have produced substantial gains, suggesting that the No Excuses model may be effective beyond the charter context.

The following section details school participation in this study, describes our data, and outlines our empirical strategy for the lottery analysis. Section III presents the findings that motivate our investigation of charter effect heterogeneity. Section IV outlines the econometric framework used to investigate this heterogeneity and reports the results of this investigation. Section V discusses our observational analysis of the connection between charter effectiveness and school practices.

\section{Lottery Analysis: Data and Empirical Strategy}

\section{A. Lottery and Survey Data}

We attempted to collect lottery data for the set of Massachusetts charter schools serving middle and high school grades and meeting a set of prespecified eligibility criteria. The school-selection process is detailed in Table 1 Schools eligible for our study accept students in the relevant entry grades (grades 4-7 for middle school and grade 9 for high school). Excluded are closed schools, schools that opened after the 2009-2010 school year, and schools serving nontraditional populations (usually students at risk of dropping out). The resulting sample includes 28 of the 34 charters with middle school entry grades and 8 of 16 schools with high school entry grades. ${ }^{3}$ Eligible schools omitted from the lottery analysis were either undersubscribed or failed to keep lottery records adequate for our study. The final sample of oversubscribed schools with usable records includes 17 middle schools and 6 high schools. These schools are listed in online Appendix Table A1. The lottery sample includes nine urban middle schools, eight nonurban middle schools, four urban high schools, and two nonurban high schools. ${ }^{4}$

In an effort to document differences in school practice, we surveyed the full set of eligible charter schools, regardless of the quality of their lottery records. Twenty-four school administrators completed this survey. ${ }^{5}$ The survey is described in detail in the online Survey Appendix. As shown in panel A of Table 2, the survey

\footnotetext{
${ }^{3}$ Three eligible schools serve both middle and high school grades, so there are 33 eligible campuses. Schools are classified as both middle and high if they have entrance lotteries at both levels, or if lottery records at the middle school level were available early enough for participants to be observed in high school.

${ }^{4}$ Urban areas are those in which the district superintendent participates in the Massachusetts Urban Superintendents Network. This defines a sample split essentially identical to that based on high poverty or high minority enrollment.

${ }^{5}$ This generates data for 27 schools since three admit in both middle and high school.
} 
TABle 1 -School Participation

\begin{tabular}{|c|c|c|c|c|c|}
\hline School level & Urban status & Boston status & $\begin{array}{c}\text { Middle (entry } \\
\text { in 4-7) and } \\
\text { high (entry in 9) } \\
\text { school charters } \\
(1)\end{array}$ & $\begin{array}{l}\text { Charters } \\
\text { eligible for } \\
\text { lottery study } \\
\text { (2) }\end{array}$ & $\begin{array}{c}\text { Charters } \\
\text { included in } \\
\text { lottery study } \\
\text { (3) }\end{array}$ \\
\hline \multirow[t]{5}{*}{ Middle } & Urban & & 22 & 17 & 9 \\
\hline & & Boston & 12 & 9 & 7 \\
\hline & & Non-Boston & 10 & 8 & 2 \\
\hline & Nonurban & & 12 & 11 & 8 \\
\hline & Total (urban and nonurban) & & 34 & 28 & 17 \\
\hline \multirow[t]{5}{*}{ High } & Urban & & 12 & 6 & 4 \\
\hline & & Boston & 8 & 5 & 4 \\
\hline & & Non-Boston & 4 & 1 & 0 \\
\hline & Nonurban & & 4 & 2 & 2 \\
\hline & Total (urban and nonurban) & & 16 & 8 & 6 \\
\hline
\end{tabular}

Notes: This table reports the number of middle and high charter schools in Massachusetts and their participation in the observational and lottery studies. Urban towns include: Boston, Brockton, Cambridge, Chelsea, Chicopee, Everett, Fall River, Fitchburg, Framingham, Haverhill, Holyoke, Lawrence, Leominster, Lowell, Lynn, Malden, New Bedford, Pittsfield, Quincy, Revere, Somerville, Springfield, Taunton, and Worcester. Three schools with lotteries at the middle school entry point which also enroll students in the high school grades are included in the high school sample.

reveals important differences between urban and nonurban charter schools. Urban schools are younger than nonurban schools. In spring 2010, the average urban school had been open for 8.6 years, while the average nonurban school had been open for 12.4 years. Urban charter schools also run a longer school day and year than do nonurban schools. The average urban charter year lasts 189 days and has a school day of 471 minutes, compared to 183 days and 440 minutes at nonurban schools. The extra time appears to go to increased math and reading instruction. Urban schools spend 27 extra minutes per day on math and 39 extra minutes per day on reading. In addition, 19 percent of urban charter schools have Saturday school, while no nonurban charter reported having school on Saturday.

Urban and nonurban schools also differ with respect to school philosophy. The survey results reveal a particularly sharp division between urban and nonurban charters with respect to the No Excuses approach to education. As discussed by Thernstrom and Thernstrom (2003) and Carter (2000), No Excuses principles include an emphasis on student behavior and comportment, extended time in school, an intensive focus on traditional reading and math skills, and teacher quality. Twothirds of urban charter administrators identify somewhat or fully with No Excuses pedagogy, while no nonurban charter identifies with this approach. We provide further details on differences in school practice in Section V.

Panel B of Table 2 compares the inputs and resources used by urban charters, nonurban charters, and traditional public schools. ${ }^{6}$ All urban charters qualify for Federal Title I funds. Urban charters spend about as much as traditional public schools, while nonurban charter schools spend less $(\$ 13,668$ compared to $\$ 11,091)$. Compared to nonurban charters and public schools, urban charters have substantially younger teachers. Probably due to these age differences, urban charter teachers are

\footnotetext{
${ }^{6}$ Characteristics of traditional public schools were gathered from http://profiles.doe.mass.edu and refer to the 2010-2011 school year. Our survey measures are unavailable for traditional public schools.
} 
Table 2-Characteristics of Charter and Public Schools

\begin{tabular}{|c|c|c|c|c|}
\hline & $\begin{array}{c}\text { All } \\
\text { charters } \\
(1)\end{array}$ & $\begin{array}{c}\text { Urban } \\
\text { charters } \\
(2)\end{array}$ & $\begin{array}{c}\text { Nonurban } \\
\text { charters } \\
(3)\end{array}$ & $\begin{array}{c}\text { Traditional } \\
\text { public schools } \\
\text { (4) }\end{array}$ \\
\hline \multicolumn{5}{|l|}{ Panel A. Charter school characteristics } \\
\hline Years open & 10.1 & 8.6 & 12.4 & - \\
\hline Days per year & 186 & 189 & 183 & - \\
\hline Average minutes per day & 463 & 471 & 440 & - \\
\hline Saturday school & 0.14 & 0.19 & 0.00 & - \\
\hline Average math instruction (min) & 91 & 97 & 70 & - \\
\hline Average reading instruction (min) & 84 & 91 & 52 & - \\
\hline No excuses & 0.41 & 0.67 & 0.00 & - \\
\hline \multicolumn{5}{|l|}{ Panel B. Comparison with traditional public schools } \\
\hline Proportion of teachers 32 and younger & 0.56 & 0.70 & 0.33 & 0.20 \\
\hline Proportion of teachers 49 and older & 0.17 & 0.08 & 0.31 & 0.42 \\
\hline Proportion of teachers licensed to teach assignment & 0.64 & 0.62 & 0.67 & 0.98 \\
\hline Proportion of core classes taught by highly qualified teachers & 0.94 & 0.92 & 0.98 & 0.98 \\
\hline Student/teacher ratio & 12.0 & 12.6 & 11.1 & 15.2 \\
\hline Average per-pupil expenditure & $\$ 12,618$ & $\$ 13,668$ & $\$ 11,091$ & $\$ 13,047$ \\
\hline Title I eligible & 0.86 & 1.00 & 0.64 & 0.50 \\
\hline Observations (schools) & 27 & 18 & 9 & 1,810 \\
\hline
\end{tabular}

Notes: This table reports characteristics of Massachusetts charter and traditional schools. Charter school characteristics come from a survey of school administrators. Panel B compares charter schools to traditional public schools using data from state school profiles. Column 1 reports results from our statewide sample of charter schools with entry in middle (4th-7th) or high school (9th) grades. The charter sample excludes schools closed prior to Spring 2011, schools that opened after Spring 2010, and schools serving nontraditional student populations. Columns 2 and 3 show results for the urban and nonurban charter subsamples. Column 4 reports teacher characteristics for all traditional public schools in Massachusetts. Highly qualified teachers are teachers that possess a Massachusetts teaching license and demonstrate subject matter competency, either by passing a subject test or meeting one of several other criteria.

less likely to be licensed than traditional public school teachers. Student/teacher ratios at charter schools are generally smaller than staff ratios at traditional public schools; nonurban charter schools have the smallest classes.

\section{B. Student Data}

The student-level data used here come from administrative records covering all public schools in Massachusetts.7 Our sample covers the 2001-2002 school year through the 2010-2011 school year. The administrative records include information on demographics and school(s) attended, as well as Massachusetts Comprehensive Assessment System (MCAS) scores. The MCAS is a set of high-stakes standardized tests given to students in grades 3-8 and grade 10 . The primary outcomes analyzed in our study are math and English Language Arts (ELA) scores. The online Data Appendix provides details on the availability of outcomes for each applicant cohort. Raw MCAS scores were standardized by subject, grade level, and year.

The lottery analysis sample matches applicant records to administrative data using applicants' names, cohorts, and grades. Where available, information on date of birth, town of residence, race/ethnicity, and gender was used to break ties.

\footnotetext{
details.

${ }^{7}$ Records are from the Student Information Management System, or SIMS. See the online Data Appendix for
} 
Ninety-two percent of applicants were matched. Applicants were excluded from the lottery analysis if they were disqualified from the lottery they entered (this mostly affected applicants to the wrong grade level). We also dropped siblings of current students, late applicants, and some out-of-area applicants. ${ }^{8}$ Students missing baseline demographic information in the state database were dropped as well.

\section{Descriptive Statistics}

We begin with a statistical picture of the Massachusetts student population in traditional public and charter schools, presented in Table 3 separately for urban and nonurban areas. Traditional schools are defined as those that are not charters, alternative programs for older students, exclusively special education, exam, or magnet schools. The table shows average demographic characteristics, participation rates in limited English proficiency (LEP) and special education (SPED) programs, and average baseline test scores. Baseline (pre-charter enrollment) scores are from grade 4 for middle school and grade 8 for high school.

Traditional urban students are unlike traditional students in the rest of the state. Specifically, urban students are more likely to be black or Hispanic, to participate in LEP or SPED programs, and to receive a subsidized lunch. Urban students also have much lower baseline test scores than other public school students, with scores $0.43 \sigma$ and $0.47 \sigma$ below the state average in math and ELA at the middle school level, and $0.42 \sigma$ and $0.39 \sigma$ below the average for high school. In contrast, nonurban students score $0.21 \sigma$ and $0.23 \sigma$ above the middle school average; the corresponding nonurban advantages in high school are $0.27 \sigma$ and $0.28 \sigma$.

Eligible charter school students who live in urban and nonurban areas are more similar to their peers in regular public schools than to one another. On the other hand, we see important differences by charter status as well. Urban charter schools serve a higher proportion of black students than do urban public schools. Urban charter students are also less likely to participate in LEP or SPED programs, or to qualify for a subsidized lunch. Charter school students in both urban and nonurban areas have baseline test scores that are slightly higher than those of their public school counterparts. In samples from both urban and nonurban areas, charter applicants for whom we have lottery data appear similar to the corresponding samples of all charter students.

\section{Empirical Strategy}

Our lottery-based identification strategy captures causal effects for applicants to over-subscribed charters with high-quality lottery records. The second-stage equation for the lottery analysis is

$$
y_{i g t}=\alpha_{2 t}+\beta_{2 g}+\sum_{j} \delta_{j} d_{i j}+X_{i}^{\prime} \theta+\tau s_{i g t}+\epsilon_{i g t},
$$

\footnotetext{
${ }^{8}$ Charter schools typically give priority to sibling applicants, as well as to students in the local school district or region. Our applicant risk sets (discussed in the next section) distinguish between in-area and out-of-area applicants for schools that take substantial numbers of both. Out-of-area applicants were dropped at schools with fewer than five in this category.
} 
TABle 3-Descriptive Statistics For Students

\begin{tabular}{|c|c|c|c|c|c|c|}
\hline & \multicolumn{2}{|c|}{$\begin{array}{l}\text { Traditional public } \\
\text { school students }\end{array}$} & \multicolumn{2}{|c|}{$\begin{array}{l}\text { Charter } \\
\text { students }\end{array}$} & \multicolumn{2}{|c|}{$\begin{array}{l}\text { Charter lottery } \\
\text { applicants }\end{array}$} \\
\hline & $\begin{array}{l}\text { Urban } \\
(1)\end{array}$ & $\begin{array}{c}\text { Nonurban } \\
(2)\end{array}$ & $\begin{array}{l}\text { Urban } \\
(3)\end{array}$ & $\begin{array}{c}\text { Nonurban } \\
(4)\end{array}$ & $\begin{array}{c}\text { Urban } \\
(5)\end{array}$ & $\begin{array}{c}\text { Nonurban } \\
(6)\end{array}$ \\
\hline \multicolumn{7}{|c|}{ Panel A. Middle schools (5th-8th grade) } \\
\hline Female & 0.486 & 0.488 & 0.501 & 0.478 & 0.496 & 0.509 \\
\hline Black & 0.183 & 0.027 & 0.381 & 0.035 & 0.479 & 0.022 \\
\hline Hispanic & 0.319 & 0.038 & 0.246 & 0.039 & 0.233 & 0.025 \\
\hline Special education & 0.191 & 0.165 & 0.167 & 0.158 & 0.176 & 0.185 \\
\hline Subsidized lunch & 0.687 & 0.146 & 0.642 & 0.211 & 0.686 & 0.103 \\
\hline Limited English proficiency & 0.160 & 0.017 & 0.082 & 0.022 & 0.085 & 0.008 \\
\hline Baseline math score & -0.427 & 0.210 & -0.322 & 0.259 & -0.356 & 0.305 \\
\hline Baseline ELA score & -0.466 & 0.232 & -0.312 & 0.275 & -0.375 & 0.391 \\
\hline Years in charter & 0.00 & 0.00 & 2.09 & 1.97 & 1.59 & 1.25 \\
\hline Observations (students) & 171,703 & 415,794 & 8,388 & 9,070 & 4,155 & 1,701 \\
\hline Observations (schools) & 262 & 400 & 17 & 11 & 9 & 8 \\
\hline \multicolumn{7}{|c|}{ Panel B. High schools (10th grade) } \\
\hline Female & 0.499 & 0.494 & 0.557 & 0.545 & 0.548 & 0.538 \\
\hline Black & 0.189 & 0.028 & 0.527 & 0.021 & 0.614 & 0.028 \\
\hline Hispanic & 0.275 & 0.034 & 0.183 & 0.010 & 0.257 & 0.017 \\
\hline Special education & 0.172 & 0.156 & 0.166 & 0.109 & 0.178 & 0.114 \\
\hline Subsidized lunch & 0.612 & 0.126 & 0.608 & 0.146 & 0.717 & 0.123 \\
\hline Limited English proficiency & 0.094 & 0.009 & 0.024 & 0.004 & 0.035 & 0.003 \\
\hline Baseline math score & -0.420 & 0.268 & -0.371 & 0.321 & -0.320 & 0.440 \\
\hline Baseline ELA score & -0.392 & 0.278 & -0.318 & 0.412 & -0.315 & 0.552 \\
\hline Years in charter & 0.00 & 0.00 & 1.77 & 1.81 & 0.64 & 1.30 \\
\hline Observations (students) & 132,774 & 357,733 & 2,676 & 909 & 3,029 & 351 \\
\hline Observations (schools) & 104 & 316 & 6 & 2 & 4 & 2 \\
\hline
\end{tabular}

Notes: This table reports descriptive statistics for the sample of public school students (columns 1 and 2), the sample of students in charter schools eligible for the study (columns 3 and 4), and our lottery sample of charter applicants (columns 5 and 6) from 2002-2011. All samples include only students in Massachusetts public schools at baseline with at least one followup test score. The number of schools in columns 1 and 2 is counted in sixth grade for middle school and tenth grade for high school. Years in charter school is measured as time spent in eligible charter schools through eighth grade for middle school and tenth grade for high school.

where $y_{i g t}$ is a test score for student $i$ in grade $g$ in year $t, \alpha_{2 t}$ and $\beta_{2 g}$ are year and grade effects, $X_{i}$ is a vector of pre-lottery demographic characteristics (sex, race, special education, limited English proficiency, subsidized lunch status, and a female-minority interaction term), and $\epsilon_{i g t}$ is an error term. The set of $d_{i j}$ includes a separate dummy variable for every combination of charter school lotteries applied to by applicants in the lottery sample. In what follows, we refer to these combinations as "risk sets." (Lottery offers are randomly assigned within risk sets but not unconditionally.) Our treatment variable, $s_{i g t}$, measures years spent in charter schools between application and test dates. ${ }^{9}$

Ordinary least squares (OLS) estimates of $\tau$ in equation (1) fail to capture causal effects if the decision to apply to or attend a charter school is correlated with unmeasured ability, motivation, or family background. We therefore use a dummy variable,

\footnotetext{
${ }^{9}$ Students who transfer between public schools are assigned to the school attended longest in a given year. Students with any charter attendance are coding as having been in charter for the year. Students attending multiple charters in a given year are coded as having been a student at the charter school attended longest. The variable $s_{i g t}$ counts years spent at any charter school, including those without lottery records.
} 
$Z_{i}$, indicating lottery offers as an instrumental variable for time spent in charter school. The first stage for this two-stage least squares (2SLS) procedure is

$$
s_{i g t}=\alpha_{1 t}+\beta_{1 g}+\sum_{j} \kappa_{j} d_{i j}+X_{i}^{\prime} \mu+\pi Z_{i}+\eta_{i g t},
$$

where $\pi$ is the effect of a lottery offer on charter attendance. As in the second-stage equation, the first stage includes risk set controls and baseline demographic characteristics, as well as year and grade effects. Estimates for high school applicants are for grade 10 MCAS scores, with standard errors clustered by school/grade/year. Samples for middle school include all non-repeat, post-lottery test scores through grade 8 and add a second layer of clustering at the student level.

The online Appendix presents evidence in support of the lottery-based identification strategy. Specifically, Table A2 shows that conditional on risk set, winning the lottery is uncorrelated with student characteristics. Online Appendix Table A3 shows that MCAS outcomes scores are available for roughly 90 percent of middle school applicants and 75 percent of high school applicants. Score availability is two points higher for lottery winners than losers in the middle school sample, but this small imbalance is unlikely to be important for the estimates discussed below. ${ }^{10}$

Differences in effectiveness between urban and nonurban charter schools are a primary focus of our analysis. Area-specific 2SLS estimates of charter effectiveness were constructed using equations of the form

$$
y_{i g t}=\alpha_{2 t}+\beta_{2 g}+\sum_{j} \delta_{j} d_{i j}+X_{i}^{\prime} \theta+\tau_{u} s_{i g t}^{u}+\tau_{n} s_{i g t}^{n}+\epsilon_{i g t},
$$

where $s_{i g t}^{u}$ and $s_{i g t}^{n}$ are years in urban and nonurban charter schools. The first stage for urban charter attendance can be written

$$
s_{i g t}^{u}=\alpha_{1 t}+\beta_{1 g}+\sum_{j} \kappa_{j} d_{i j}+X_{i}^{\prime} \mu+\pi_{u} Z_{i}^{u}+\pi_{n} Z_{i}^{n}+\eta_{i g t},
$$

where $Z_{i}^{u}$ and $Z_{i}^{n}$ indicate offers from urban and nonurban charters, with a similar specification for nonurban charter attendance.

\section{Lottery Estimates}

The first-stage estimates reported in column 1 of Table 4 show that, among applicants to charter middle schools, students who won a charter school lottery spent about one year more in a charter before being tested than did students who were not offered a seat. Applicants who won high school entrance lotteries spent a little over half a year longer in a charter school between application and testing than applicants who lost. These first-stage estimates are similar to those reported in Abdulkadiroğlu et al. (2011) for a smaller sample of charter schools in Boston.

\footnotetext{
${ }^{10}$ Online Table A2 shows that lottery offers are uncorrelated with student characteristics in both urban and nonurban areas. Columns 3 and 5 of online Table A3 show that follow-up rates are similar for urban and nonurban charters. Differences in follow-up rates between winners and losers are slightly higher for nonurban schools at both levels.
} 
TABle 4-LotTery Estimates of Charter EfFects

\begin{tabular}{|c|c|c|c|c|c|c|}
\hline \multirow[b]{2}{*}{ Subject } & \multicolumn{2}{|c|}{ All charter schools } & \multicolumn{2}{|c|}{ Urban charter schools } & \multicolumn{2}{|c|}{ Nonurban charter schools } \\
\hline & $\begin{array}{l}\text { First stage } \\
\text { (1) }\end{array}$ & $\begin{array}{l}2 \text { SLS } \\
(2)\end{array}$ & $\begin{array}{l}\text { First stage } \\
\text { (3) }\end{array}$ & $\begin{array}{l}2 \text { SLS } \\
(4)\end{array}$ & $\begin{array}{l}\text { First stage } \\
\qquad(5)\end{array}$ & $\begin{array}{l}2 \mathrm{SLS} \\
(6)\end{array}$ \\
\hline $\begin{array}{l}\text { Panel A. Middle school } \\
\text { Math }\end{array}$ & $\begin{array}{l}1.02 * * * \\
(0.040)\end{array}$ & $\begin{array}{l}0.213 * * * \\
(0.028)\end{array}$ & $\begin{array}{l}1.03 * * * \\
(0.051)\end{array}$ & $\begin{array}{l}0.321 * * * \\
(0.031)\end{array}$ & $\begin{array}{l}1.01 * * * \\
(0.074)\end{array}$ & $\begin{array}{l}-0.123 * * * \\
(0.047)\end{array}$ \\
\hline $\mathrm{N}$ & \multicolumn{2}{|c|}{16,543} & \multicolumn{2}{|c|}{11,941} & \multicolumn{2}{|c|}{4,602} \\
\hline ELA & $\begin{array}{l}1.02 * * * \\
(0.040)\end{array}$ & $\begin{array}{l}0.075^{* * * *} \\
(0.025)\end{array}$ & $\begin{array}{l}1.04 * * * \\
(0.051)\end{array}$ & $\begin{array}{l}0.146^{* * * *} \\
(0.028)\end{array}$ & $\begin{array}{l}1.00 * * * \\
(0.074)\end{array}$ & $\begin{array}{c}-0.144 * * * \\
(0.039)\end{array}$ \\
\hline $\mathrm{N}$ & \multicolumn{2}{|c|}{16,285} & \multicolumn{2}{|c|}{11,649} & \multicolumn{2}{|c|}{4,636} \\
\hline $\begin{array}{l}\text { Panel B. High school } \\
\text { Math }\end{array}$ & $\begin{array}{l}0.565 * * * \\
(0.085)\end{array}$ & $\begin{array}{l}0.273 * * * \\
(0.071)\end{array}$ & $\begin{array}{l}0.508 * * * \\
(0.090)\end{array}$ & $\begin{array}{l}0.339 * * * \\
(0.077)\end{array}$ & $\begin{array}{l}1.13 * * * \\
(0.197)\end{array}$ & $\begin{array}{r}-0.020 \\
(0.071)\end{array}$ \\
\hline $\mathrm{N}$ & \multicolumn{2}{|c|}{4,050} & \multicolumn{2}{|c|}{3,519} & \multicolumn{2}{|c|}{531} \\
\hline ELA & $\begin{array}{l}0.565 * * * \\
(0.086)\end{array}$ & $\begin{array}{l}0.206^{* * * *} \\
(0.060)\end{array}$ & $\begin{array}{l}0.508 * * * \\
(0.090)\end{array}$ & $\begin{array}{l}0.264 * * * \\
(0.067)\end{array}$ & $\begin{array}{l}1.14 * * * \\
(0.196)\end{array}$ & $\begin{array}{r}-0.046 \\
(0.059)\end{array}$ \\
\hline $\mathrm{N}$ & \multicolumn{2}{|c|}{4,103} & \multicolumn{2}{|c|}{3,567} & \multicolumn{2}{|c|}{536} \\
\hline
\end{tabular}

Notes: This table reports 2SLS estimates of the effects of time spent in charter schools on test scores. The endogenous variable is years spent in charter schools and the instrument is a lottery offer dummy. Columns 1-2 show estimates for all schools, columns 3-4 show estimates for urban charter schools, and columns 5-6 show estimates for nonurban schools. The urban and nonurban estimates for a given subject come from a single regression with two endogenous variables, using urban and nonurban offers as instruments. All models control for race, sex, special education, limited English proficiency, subsidized lunch status, and a female by minority dummy. Year of birth, year of test, and risk set dummies are also included. Estimates for the middle school sample pool post-lottery outcomes for grades 4-8 and cluster by student identifier as well as school-grade-year. Estimates for the high school sample include only scores for tenth grade and cluster by school-grade-year.

*** Significant at the 1 percent level.

** Significant at the 5 percent level.

* Significant at the 10 percent level.

Second stage estimates for the full sample of lottery schools appear in column 2 of Table 4. These imply that a year of attendance at a lottery sample charter middle school increases math scores by $0.21 \sigma$ and ELA scores by $0.08 \sigma$. The high school 2SLS estimates reveal larger causal effects, with score gains on the order of $0.27 \sigma$ per year for math and $0.21 \sigma$ per year for ELA. ${ }^{11}$

Estimates for the full state sample mask considerable heterogeneity by urban status, a pattern documented in columns 3 through 6 of Table 4. Although first stages at urban and nonurban middle schools are similar, the corresponding second-stage estimates differ markedly. 2SLS estimates for urban middle schools, reported in column 4 of Table 4, suggest these schools generate gains of $0.32 \sigma$ in math and $0.15 \sigma$ in ELA per year enrolled. In contrast, estimates for nonurban charter middle schools are negative. In particular, as can be seen in column 6 , charter students at nonurban middle schools appear to lose ground relative to their public school peers at a rate of $0.12 \sigma$ per year in math and $0.14 \sigma$ per year in ELA. Not surprisingly, high school lottery results for urban schools are similar to the statewide results (since only two of the high schools in the state sample are nonurban), showing large gains in math

\footnotetext{
${ }^{11}$ Our earlier working paper reports results for writing scores similar to those for ELA (Angrist, Pathak, and Walters 2011).
} 
and ELA. ${ }^{12}$ On the other hand, 2SLS estimates for nonurban charter high schools are small, negative, and not significantly different from zero..$^{13}$

Variation in charter effects across demographic groups is documented in Table 5, separately for urban and nonurban schools. Urban charter schools boost scores for most applicants, though not uniformly. Girls realize slightly larger gains in math, while boys see slightly larger ELA gains. Black and Hispanic students benefit considerably from urban charter attendance in middle school, but the estimated math gains for whites are smaller, with no increase in whites' ELA scores. Urban charter middle schools appear to produce especially large achievement gains for students eligible for a subsidized lunch and for those with low baseline scores. Attendance at urban charter high schools increases math scores in every group and raises reading scores for everyone except whites, though estimates for small groups are imprecise.

Nonurban charter attendance fails to raise scores for most of the groups examined in Table 5, and appears to reduce achievement for girls, whites, and students with low baseline scores in middle school. Estimates for nonurban black and Hispanic middle school students are negative, though not significantly different from zero. Most of the estimates for nonurban charter high school students are close to zero, though effects here are less precisely estimated than those for nonurban middle school (high school estimates for blacks and Hispanics are omitted due to the small size of these nonurban groups). ${ }^{14}$

\section{Differences in Students}

We investigate student- and school-level explanations for the striking difference in achievement effects at urban and nonurban charter schools. The student-level analysis is cast in a semiparametric framework with heterogeneous potential outcomes, indexed against a Bernoulli treatment, $D_{i} \in\{0,1\}$, to indicate charter attendance. The Bernoulli setup focuses on heterogeneity, while abstracting from nonlinearities that seem second-order in this context (the first stage effects of lottery offers are similar in the two settings for middle school, yet the corresponding second stage estimates differ dramatically). Let $Y_{1 i}$ and $Y_{0 i}$ denote potential test scores for student $i$ in and out of charter school. The observed outcome for student $i$ is

$$
Y_{i}=Y_{0 i}+\left(Y_{1 i}-Y_{0 i}\right) D_{i} .
$$

In other words, we observe $Y_{0 i}$ for applicants who don't go to charter school and $Y_{1 i}$ for those who do.

\footnotetext{
${ }^{12}$ We also looked at the effects of charter attendance on high school graduation rates. Online Appendix Table A4 shows 2SLS estimates of equations (1) and (3) for graduation, with the endogenous variable coded as a dummy for attending a charter in the year after the lottery. This analysis suggests that attending a charter has little effect on the probability of high school graduation.

${ }^{13}$ As shown in columns 3 and 5 of Table 4, the first stage for urban high schools is smaller than the first stage for nonurban high schools. This difference reflects the fact that a larger proportion of the nonurban high school sample comes from entrance lotteries in middle grades, generating more potential years of charter exposure by the time applicants were tested in high school.

${ }^{14}$ Clustering the nonurban high school standard errors by school-grade-year as in Table 4 produced standard errors that were much smaller than classical homoskedastic 2SLS standard errors, suggesting finite-sample bias due to clustering. To avoid this bias, we report $p$-values from 1,000 replications of the wild cluster bootstrap percentile- $t$ procedure described by Cameron, Gelbach, and Miller (2008).
} 
TABLE 5-LotTery Estimates For Subgroups

\begin{tabular}{|c|c|c|c|c|c|c|c|}
\hline \multirow[b]{2}{*}{$\begin{array}{l}\text { School } \\
\text { level }\end{array}$} & \multirow[b]{2}{*}{ Subject } & \multicolumn{2}{|c|}{ Sex } & \multicolumn{2}{|c|}{ Race } & \multirow[b]{2}{*}{$\begin{array}{l}\text { Subsidized } \\
\text { lunch } \\
(5)\end{array}$} & \multirow{2}{*}{$\begin{array}{c}\text { Lowest } \\
\text { baseline } \\
\text { quartile } \\
(6)\end{array}$} \\
\hline & & $\begin{array}{c}\text { Female } \\
(1)\end{array}$ & $\begin{array}{c}\text { Male } \\
(2)\end{array}$ & $\begin{array}{c}\text { Black/ } \\
\text { Hispanic } \\
(3)\end{array}$ & $\begin{array}{l}\text { White } \\
(4)\end{array}$ & & \\
\hline \multicolumn{8}{|c|}{ Panel A. Urban schools } \\
\hline Middle & Math & $\begin{array}{l}0.379 * * * \\
(0.042)\end{array}$ & $\begin{array}{l}0.276^{* * * *} \\
(0.041)\end{array}$ & $\begin{array}{l}0.421 \text { *** } \\
(0.040)\end{array}$ & $\begin{array}{l}0.133 * * \\
(0.054)\end{array}$ & $\begin{array}{l}0.348^{* * *} \\
(0.036)\end{array}$ & $\begin{array}{l}0.388 * * * \\
(0.055)\end{array}$ \\
\hline \multirow[t]{2}{*}{$\mathrm{N}$} & & 5,994 & 5,947 & 8,415 & 2,583 & 8,182 & 2,869 \\
\hline & ELA & $\begin{array}{l}0.124 * * * \\
(0.037)\end{array}$ & $\begin{array}{l}0.173^{* * * *} \\
(0.040)\end{array}$ & $\begin{array}{l}0.211^{* * *} * \\
(0.037)\end{array}$ & $\begin{array}{c}0.034 \\
(0.047)\end{array}$ & $\begin{array}{l}0.182^{* * * *} \\
(0.033)\end{array}$ & $\begin{array}{l}0.279 * * * \\
(0.057)\end{array}$ \\
\hline $\mathrm{N}$ & & 5,852 & 5,797 & 8,176 & 2,537 & 7,992 & 2,840 \\
\hline High & Math & $\begin{array}{l}0.368^{* * * *} \\
(0.087)\end{array}$ & $\begin{array}{l}0.319^{* * * *} \\
(0.105)\end{array}$ & $\begin{array}{l}0.378^{* * * *} \\
(0.074)\end{array}$ & $\begin{array}{c}0.168 \\
(0.235)\end{array}$ & $\begin{array}{l}0.348^{* * * *} \\
(0.080)\end{array}$ & $\begin{array}{l}0.444 * * * \\
(0.104)\end{array}$ \\
\hline \multirow[t]{2}{*}{$\mathrm{N}$} & & 1,928 & 1,591 & 3,018 & 310 & 2,521 & 811 \\
\hline & ELA & $\begin{array}{l}0.236^{* * * *} \\
(0.077)\end{array}$ & $\begin{array}{l}0.279 * * * \\
(0.095)\end{array}$ & $\begin{array}{l}0.325^{* * *} * \\
(0.067)\end{array}$ & $\begin{array}{c}-0.063 \\
(0.221)\end{array}$ & $\begin{array}{l}0.275^{* * * *} \\
(0.071)\end{array}$ & $\begin{array}{l}0.251 * * \\
(0.123)\end{array}$ \\
\hline $\mathrm{N}$ & & 1,955 & 1,612 & 3,061 & 311 & 2,557 & 768 \\
\hline \multicolumn{8}{|c|}{ Panel B. Nonurban schools } \\
\hline Middle & Math & $\begin{array}{c}-0.159 * * * \\
(0.060)\end{array}$ & $\begin{array}{r}-0.084 \\
(0.070)\end{array}$ & $\begin{array}{r}-0.230 \\
(0.285)\end{array}$ & $\begin{array}{c}-0.115^{* *} \\
(0.045)\end{array}$ & $\begin{array}{r}-0.128 \\
(0.127)\end{array}$ & $\begin{array}{c}-0.159 * * \\
(0.071)\end{array}$ \\
\hline \multirow[t]{2}{*}{$\mathrm{N}$} & & 2,332 & 2,270 & 236 & 4,135 & 456 & 1,072 \\
\hline & ELA & $\begin{array}{c}-0.169 * * * \\
(0.049)\end{array}$ & $\begin{array}{c}-0.114^{*} \\
(0.060)\end{array}$ & $\begin{array}{r}-0.241 \\
(0.251)\end{array}$ & $\begin{array}{c}-0.150 * * * \\
(0.040)\end{array}$ & $\begin{array}{r}-0.119 \\
(0.099)\end{array}$ & $\begin{array}{c}-0.188^{* *} \\
(0.076)\end{array}$ \\
\hline $\mathrm{N}$ & & 2,348 & 2,288 & 237 & 4,169 & 466 & 1,134 \\
\hline High & Math & $\begin{array}{c}0.005 \\
{[0.959]}\end{array}$ & $\begin{array}{c}0.052 \\
{[0.670]}\end{array}$ & - & $\begin{array}{c}0.039 \\
{[0.627]}\end{array}$ & $\begin{array}{c}0.427 \\
{[0.389]}\end{array}$ & $\begin{array}{c}-0.097 \\
{[0.438]}\end{array}$ \\
\hline \multirow[t]{2}{*}{$\mathrm{N}$} & & 281 & 250 & & 494 & 68 & 119 \\
\hline & ELA & $\begin{array}{c}0.034 \\
{[0.717]} \\
281\end{array}$ & $\begin{array}{c}-0.062 \\
{[0.382]} \\
255\end{array}$ & - & $\begin{array}{c}-0.028 \\
{[0.559]} \\
496\end{array}$ & $\begin{array}{c}-0.392 \\
{[0.368]} \\
71\end{array}$ & $\begin{array}{c}0.054 \\
{[0.709]} \\
123\end{array}$ \\
\hline $\mathrm{N}$ & & 281 & 255 & & 496 & 71 & 123 \\
\hline
\end{tabular}

Notes: This table reports 2SLS estimates of the effects of time spent in charter schools on demographic subgroups. All regressions include year dummies, grade dummies, risk set dummies, and demographic controls. Middle school standard errors are clustered on student identifier as well as school-grade-year. High school standard errors are clustered by school-grade-year for urban schools. For nonurban high schools, numbers in brackets show $p$-values from 1,000 replications of a wild bootstrap percentile- $t$ procedure clustered on school-grade-year.

*** Significant at the 1 percent level.

** Significant at the 5 percent level.

* Significant at the 10 percent level.

Our empirical work uses data from many school- and cohort-specific admissions lotteries, but the the theory behind our heterogeneity analysis is detailed with reference to a single lottery. Offers in this lottery are indicated by $Z_{i}$, as before. Potential treatment assignments, denoted $D_{1 i}$ and $D_{0 i}$, tell us whether student $i$ attends a charter school if he wins or loses the lottery. Offers are randomly assigned and assumed to affect test scores only through charter attendance, so the potential outcome vector $\left(Y_{1 i}, Y_{0 i}, D_{1 i}, D_{0 i}\right)$ is independent of $Z_{i}$. We also assume that winning an entrance lottery can only make charter attendance more likely, so that $D_{1 i} \geq D_{0 i} \forall i$, with strict inequality for some students. 
Under these assumptions, instrumental variables estimation using $Z_{i}$ as an instrument for $D_{i}$ in the sample of lottery applicants produces a local average treatment effect (LATE; Imbens and Angrist 1994). Here, LATE is the effect of charter attendance for students induced to enroll in a charter school by winning an admissions lottery. This is the population of lottery compliers, who have $D_{1 i}>D_{0 i}$. When computed separately for urban and nonurban students, IV estimates identify

$$
\begin{aligned}
\tau_{\ell} & \equiv \frac{E_{\ell}\left[Y_{i} \mid Z_{i}=1\right]-E_{\ell}\left[Y_{i} \mid Z_{i}=0\right]}{E_{\ell}\left[D_{i} \mid Z_{i}=1\right]-E_{\ell}\left[D_{i} \mid Z_{i}=0\right]} \\
& =E_{\ell}\left[Y_{1 i}-Y_{0 i} \mid D_{1 i}>D_{0 i}\right], \quad \ell \in\{u, n\} ;
\end{aligned}
$$

where $\ell$ indexes location; $E_{\ell}$ denotes an expectation over students in location $\ell$; and $u$ and $n$ indicate urban and nonurban locations, respectively. This is LATE for compliers in each setting.

We pinpoint two sources of student-level heterogeneity that might contribute to the difference between $\tau_{u}$ and $\tau_{n}$. The first is variation in $Y_{0 i}$ across charter and noncharter students within each area. This investigation tells us whether charter applicants and/or charter lottery compliers are unusual in either setting, as measured by their public school achievement. Second, we use a Blinder (1973)-Oaxaca (1973) decomposition to separate the difference in charter effectiveness across areas into a component due to differences in student populations and a component due to differences in effectiveness conditional on student characteristics. This analysis tells us how much of the urban charter advantage arises from the fact that urban charters serve groups especially likely to benefit from charter attendance.

\section{A. Potential-Outcome Gaps in Urban and Nonurban Areas}

LATE can be split into two parts, the first capturing differences in potential outcomes in the treated state (differences in $Y_{1 i}$ ) and the second capturing differences in potential outcomes in the nontreated state (differences in $Y_{0 i}$ ). Specifically, we benchmark achievement in each area using the local noncharter mean. This tells us whether the urban charter advantage is driven by unusually low nontreated outcomes for urban compliers, or whether compliers are, in fact, typical of their milieu. Figure 1 illustrates the alternative scenarios we have in mind. The left panel describes a situation in which the achievement of nontreated urban students is comparable to ambient noncharter achievement, while the right panel describes a situation in which the urban fallback is unusually low.

The econometric analysis of within-area counterfactuals begins with a decomposition of urban and nonurban LATE as follows:

$$
\begin{aligned}
\tau_{\ell}= & \underbrace{E_{\ell}\left[Y_{1 i} \mid D_{1 i}>D_{0 i}\right]-E_{\ell}\left[Y_{0 i} \mid D_{i}=0\right]}_{\lambda_{1}^{\ell}} \\
& -\underbrace{\left(E_{\ell}\left[Y_{0 i} \mid D_{1 i}>D_{0 i}\right]-E_{\ell}\left[Y_{0 i} \mid D_{i}=0\right]\right)}_{\lambda_{0}^{\ell}}, \quad \ell \in\{u, n\} .
\end{aligned}
$$



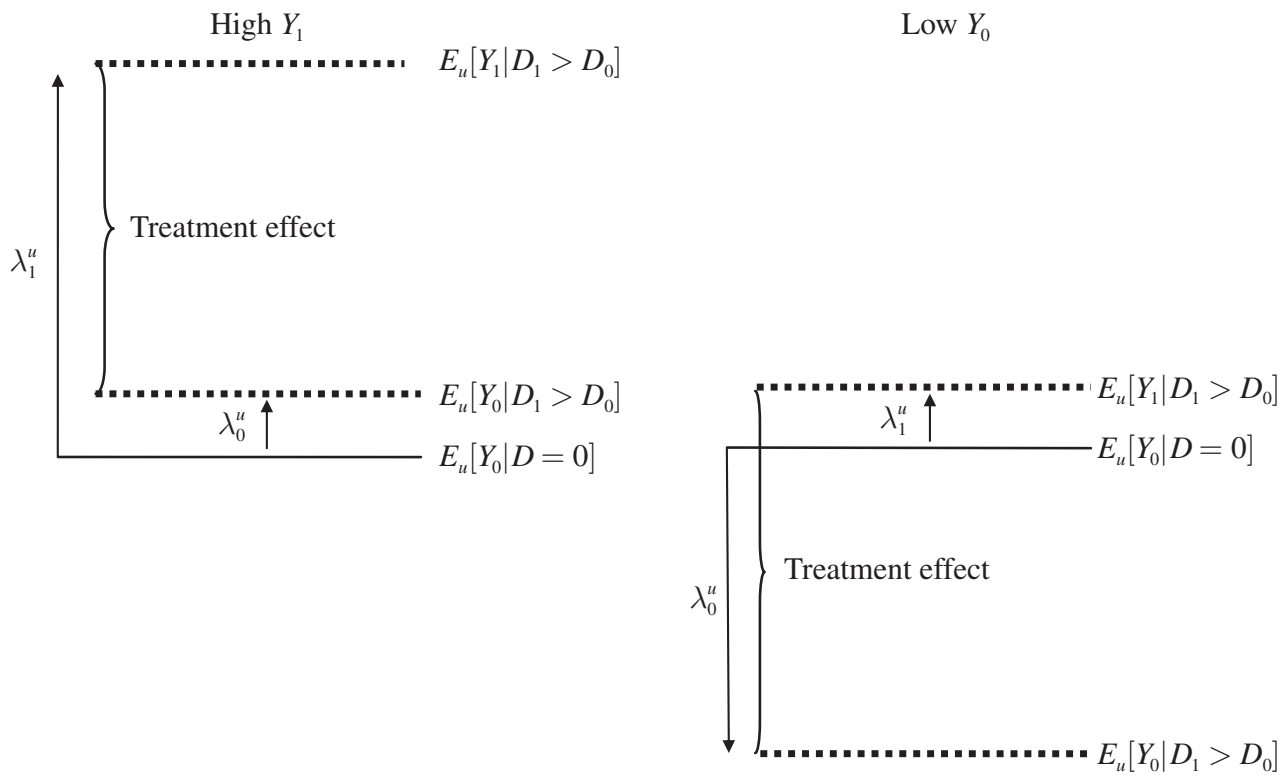

Figure 1. Two Types of Treatment Effects in Urban Areas

The term $\lambda_{0}^{\ell}$ is the difference in average $Y_{0 i}$ between lottery compliers and the general population of noncharter students in the relevant area, while $\lambda_{1}^{\ell}$ is the difference between the treated outcomes of compliers and ambient noncharter achievement. For example, large $\lambda_{1}^{u}$ and small $\lambda_{0}^{u}$ mean that urban charters push their students beyond typical noncharter achievement in cities.

Abadie (2002) shows that marginal mean $Y_{0 i}$ for compliers is given by

(6) $E_{\ell}\left[Y_{0 i} \mid D_{1 i}>D_{0 i}\right]=\frac{E_{\ell}\left[Y_{i} \cdot\left(1-D_{i}\right) \mid Z_{i}=1\right]-E_{\ell}\left[Y_{i} \cdot\left(1-D_{i}\right) \mid Z_{i}=0\right]}{E_{\ell}\left[1-D_{i} \mid Z_{i}=1\right]-E_{\ell}\left[1-D_{i} \mid Z_{i}=0\right]}$.

We estimate $\lambda_{0}^{\ell}$ by constructing the empirical analogue of equation (6) for lottery applicants in the relevant location, and subtracting the mean score for all noncharter students including nonapplicants. $\lambda_{1}^{\ell}$ is estimated using an analogous procedure that replaces $\left(1-D_{i}\right)$ with $D_{i}$ in equation $(6) .{ }^{15}$

Estimates of $\lambda_{0}^{\ell}$ and $\lambda_{1}^{\ell}$ appear in Table 6. Columns 1-4 show results for urban schools. Column 2 reports the average $Y_{0 i}$ for noncharter students, while column 3 shows $\lambda_{0}^{u}$, the difference in average nontreated outcomes between urban compliers and the scores of noncharter students. Estimates of $\lambda_{1}^{u}$, the difference between the treated outcomes of urban compliers and the ambient level of urban achievement, appear in column 4. ${ }^{16}$ The estimates of $\lambda_{0}^{u}$ suggest that urban lottery compliers are positively selected from the urban middle school population, but the estimated gaps

\footnotetext{
${ }^{15}$ The simple Wald formula given here is valid for a single lottery. Combining data from multiple lotteries, we estimate marginal complier means via a 2SLS procedure with risk set fixed effects. This produces a weighted average of within-risk-set estimates (Angrist and Imbens 1995).

${ }^{16}$ Middle school scores are from the year after the lottery for applicants and sixth grade for nonapplicants. High school scores are from tenth grade, as in earlier tables.
} 
Table 6-Potential-Outcome Gaps in Urban and Nonurban Areas

\begin{tabular}{|c|c|c|c|c|c|c|c|c|}
\hline \multirow[b]{2}{*}{ Subject } & \multicolumn{4}{|c|}{ Urban } & \multicolumn{4}{|c|}{ Nonurban } \\
\hline & $\begin{array}{l}\text { Treatment } \\
\text { effect } \\
(1)\end{array}$ & $\begin{array}{c}E_{u}\left[Y_{0} \mid D=0\right] \\
(2)\end{array}$ & $\begin{array}{r}\lambda_{0}^{u} \\
(3)\end{array}$ & $\begin{array}{l}\lambda_{1}^{u} \\
(4)\end{array}$ & $\begin{array}{l}\text { Treatment } \\
\text { effect } \\
(5)\end{array}$ & $\begin{array}{c}E_{n}\left[Y_{0} \mid D=0\right] \\
(6)\end{array}$ & $\begin{array}{l}\lambda_{0}^{n} \\
(7)\end{array}$ & $\begin{array}{l}\lambda_{1}^{n} \\
(8)\end{array}$ \\
\hline \multicolumn{9}{|c|}{ Panel A. Middle school } \\
\hline Math & $\begin{array}{l}0.483^{* * *} \\
(0.074)\end{array}$ & $\begin{array}{l}-0.399 * * * \\
(0.011)\end{array}$ & $\begin{array}{c}0.077 \\
(0.049)\end{array}$ & $\begin{array}{l}0.560 \text { *** } \\
(0.054)\end{array}$ & $\begin{array}{c}-0.177 * * \\
(0.074)\end{array}$ & $\begin{array}{l}0.236 * * * \\
(0.007)\end{array}$ & $\begin{array}{c}0.010 \\
(0.061)\end{array}$ & $\begin{array}{c}-0.143 * * * \\
(0.042)\end{array}$ \\
\hline $\mathrm{N}$ & 4,858 & & & & 2,239 & & & \\
\hline ELA & $\begin{array}{l}0.188 * * * \\
(0.064)\end{array}$ & $\begin{array}{c}-0.422 * * * \\
(0.012)\end{array}$ & $\begin{array}{l}0.118 * * \\
(0.054)\end{array}$ & $\begin{array}{l}0.306 * * * \\
(0.049)\end{array}$ & $\begin{array}{c}-0.148^{* * * *} \\
(0.048)\end{array}$ & $\begin{array}{l}0.260 * * * \\
(0.007)\end{array}$ & $\begin{array}{l}0.102 * * \\
(0.050)\end{array}$ & $\begin{array}{c}-0.086^{* * * *} \\
(0.030)\end{array}$ \\
\hline $\mathrm{N}$ & 4,551 & & & & 2,323 & & & \\
\hline \multicolumn{9}{|c|}{ Panel B. High school } \\
\hline Math & $\begin{array}{l}0.557 * * * \\
(0.164)\end{array}$ & $\begin{array}{c}-0.371 * * * \\
(0.021)\end{array}$ & $\begin{array}{c}0.074 \\
(0.099)\end{array}$ & $\begin{array}{l}0.602 * * * \\
(0.151)\end{array}$ & $\begin{array}{c}0.065 \\
(0.146)\end{array}$ & $\begin{array}{l}0.241 * * * \\
(0.008)\end{array}$ & $\begin{array}{c}0.207 \\
(0.145)\end{array}$ & $\begin{array}{l}0.271 \text { **** } \\
(0.041)\end{array}$ \\
\hline $\mathrm{N}$ & 3,743 & & & & 432 & & & \\
\hline ELA & $\begin{array}{l}0.417 \text { *** } \\
(0.140)\end{array}$ & $\begin{array}{c}-0.369^{* * *} \\
(0.018)\end{array}$ & $\begin{array}{c}-0.004 \\
(0.096)\end{array}$ & $\begin{array}{l}0.410 * * * \\
(0.119)\end{array}$ & $\begin{array}{c}0.064 \\
(0.151)\end{array}$ & $\begin{array}{l}0.250 * * * \\
(0.008)\end{array}$ & $\begin{array}{c}0.237 \\
(0.152)\end{array}$ & $\begin{array}{l}0.301 * * * \\
(0.051)\end{array}$ \\
\hline $\mathrm{N}$ & 4,858 & & & & 435 & & & \\
\hline
\end{tabular}

Notes: This table compares potential outcomes for compliers and traditional public school students. Outcomes are test scores in the year after the lottery for middle school lottery applicants and tenth grade scores for high school lottery applicants. For nonapplicants, outcomes are sixth grade scores in middle school, and tenth grade scores in high school. The treatment is a dummy for charter attendance. Columns 1 and 5 show 2SLS estimates of the effect of charter attendance on test scores in urban and nonurban areas, with the lottery offer dummy interacted with risk sets as instruments and risk set dummies as controls. Columns 2 and 6 shows average test scores for noncharter students, including nonapplicants. Columns 3 and 7 show differences between the average noncharter scores of compliers and the scores of noncharter students. Columns 4 and 8 show differences between the treated outcomes of compliers and the scores of noncharter students.

*** Significant at the 1 percent level.

** Significant at the 5 percent level.

* Significant at the 10 percent level.

are small, and (marginally) significant only for middle school ELA. Because urban charter compliers have noncharter achievement levels that are fairly typical of students in urban areas, the large score gains generated by urban charter schools can be attributed to high scores in the treated state, a fact reflected by the large, significant estimates of $\lambda_{1}^{u}$ in column 4.

Columns 7 and 8 of Table 6 report estimates of $\lambda_{0}^{n}$ and $\lambda_{1}^{n}$ for students at nonurban charter schools. As in urban areas, the noncharter achievement level of nonurban middle school compliers is slightly higher than that of students in the surrounding public schools. The ELA scores of nonurban middle school compliers in public schools exceed the ambient nonurban achievement level by a statistically significant $0.10 \sigma$, while the estimate of $\lambda_{1}^{n}$ for ELA is a precisely estimated $-0.09 \sigma$. This implies that nonurban charter middle schools move their students from atypically high ELA achievement levels to levels below those of nonurban public school students. Noncharter math achievement of nonurban middle school compliers is statistically indistinguishable from the ambient noncharter level, while nonurban charter attendance pulls compliers $0.14 \sigma$ below the noncharter mean. The results for nonurban high school students show more positive selection (high $\lambda_{0}^{n}$ ) than in middle school. As can be seen by comparing columns 7 and 8 in panel B, charter 
attendance leaves nonurban high school students essentially unchanged from this higher starting point.

These results paint a consistent picture of the urban charter advantage. Urban middle school charters push the scores of their students from a typically low level up to a level much closer to the achievement level seen among nonurban students (the scenario sketched in the left panel of Figure 1). Nonurban charter middle schools reduce the scores of their students, in some cases markedly so. The corresponding results for high schools are like those for middle schools in that urban charter high schools push their students beyond the level of achievement typical of urban public high schools. Nonurban charter high schools leave scores unchanged from a higher noncharter counterfactual baseline. ${ }^{17}$

\section{B. Accounting for Student Demographics}

The role student demographics play in generating the urban charter advantage is explored with the help of a decomposition in the spirit of Blinder (1973) and Oaxaca (1973). For example, poor, minority students may benefit the most from charter attendance, and urban charters may be more effective than nonurban charters in part because they serve larger shares of such students. The Blinder-Oaxaca framework allows us to quantify the contribution of differences in student composition to the urban charter advantage.

The first step of our Blinder-Oaxaca analysis uses the methods of Abadie (2003) to identify a linear local average response function for lottery compliers conditional on a vector of observable demographic variables, $X_{i}$. Specifically, we model causal interactions with demographics using the equation

$$
E_{\ell}\left[Y_{i} \mid D_{1 i}>D_{0 i}, D_{i}, X_{i}, d_{i j}\right]=X_{i}^{\prime} \theta_{\ell}+\omega_{\ell} D_{i}+D_{i} X_{i}^{\prime} \rho_{\ell}+\sum_{j} \delta_{j} d_{i j}, \quad \ell \in\{u, n\}
$$

This equation has a causal interpretation because conditional on being a complier, treatment status (charter enrollment) is independent of potential outcomes. The coefficient vector $\rho_{\ell}$ captures heterogeneity in LATEs across demographic groups in location $\ell$.

Equation (7) generates the following parameterization of the urban/nonurban difference in charter school attendance effects:

$$
\tau_{u}-\tau_{n}=\left(\omega_{u}-\omega_{n}\right)+\bar{X}_{n}^{\prime}\left(\rho_{u}-\rho_{n}\right)+\left(\bar{X}_{u}^{\prime}-\bar{X}_{n}^{\prime}\right) \rho_{u},
$$

where

$$
\bar{X}_{\ell} \equiv E_{\ell}\left[X_{i} \mid D_{1 i}>D_{0 i}\right]
$$

The last term in equation (8) captures the part of the urban charter advantage explained by differences in demographics. In particular, this term tells us how much

\footnotetext{
${ }^{17}$ Our working paper compares marginal mean counterfactuals for urban and nonurban compliers in more detail (Angrist, Pathak, and Walters 2011).
} 
urban charter effects are boosted by the observable characteristics of urban compliers. The first two terms capture the component of the urban advantage attributable to differences in effects within demographic groups.

Here, as always, Blinder-Oaxaca decompositions can be presented in two ways. In this case, the urban/nonurban difference in charter school impact can be decomposed with differences in means weighted by nonurban charter effects instead of urban. Specifically, we can write

$$
\tau_{u}-\tau_{n}=\left(\omega_{u}-\omega_{n}\right)+\bar{X}_{u}^{\prime}\left(\rho_{u}-\rho_{n}\right)+\left(\bar{X}_{u}^{\prime}-\bar{X}_{n}^{\prime}\right) \rho_{n} .
$$

Like equation (8), this expression includes components associated with differences in demographics and differences in effectiveness conditional on demographics. The last term measures how much more effective nonurban charter schools would be if their students were demographically similar to the urban charter population.

We construct these decompositions by estimating

$$
Y_{i}=X_{i}^{\prime} \theta_{\ell}+\omega_{\ell} D_{i}+D_{i} X_{i}^{\prime} \rho_{\ell}+\sum_{j} \delta_{j} d_{i j}+\epsilon_{i}
$$

by $2 \mathrm{SLS}$, separately for urban and nonurban applicants, with first stage for $D_{i}$

$$
D_{i}=X_{i}^{\prime} \mu_{\ell}+\pi_{\ell} Z_{i}+Z_{i} X_{i}^{\prime} \zeta_{\ell}+\sum_{j} \kappa_{j} d_{i j}+\eta_{i}
$$

and similar first stages for interaction terms involving $D_{i}$. The covariate vector, $X_{i}$, includes sex, race (white or nonwhite), special education status, free lunch status, and dummies for baseline MCAS performance at the advanced, proficient, or needs improvement level on math and ELA tests. Complier means for each component of $X_{i}$ are estimated using the kappa-weighting procedure described in Abadie (2003).

Blinder-Oaxaca decompositions suggest that favorable demographics enhance urban charter effectiveness, but differences in student populations do not fully account for the urban charter advantage. This can be seen in Table 7. which shows the components of equations (8) and (9) for middle schools. (The nonurban high school samples are too small to admit meaningful investigations of effect heterogeneity using this approach.) Column 1 shows the difference in charter middle school treatment effects by urban status. ${ }^{18}$ Columns 2 and 3 report the components of decomposition (8), which multiplies the urban/nonurban difference in demographics by treatment effects for urban schools. Column 2 shows how urban effectiveness might change if urban schools were to serve the nonurban population. These results suggest that 51 percent of the urban advantage in math $(0.32 / 0.63)$ can be explained by the level of urban demographics. The corresponding estimate for ELA is 47 percent. Urban schools are especially effective for poor and minority students, and they serve more of these students than do nonurban schools. On the other hand,

\footnotetext{
${ }^{18}$ These differences differ slightly from those reported in Table 6 because equation (10) imposes first-stage coefficients that are constant across risk sets, while the earlier estimates allow the first stage coefficients to vary.
} 
Table 7-Decomposing Differences in Middle School Charter Effects

\begin{tabular}{|c|c|c|c|c|c|}
\hline \multirow[b]{2}{*}{ Subject } & \multirow[b]{2}{*}{$\begin{array}{c}\text { Urban versus } \\
\text { nonurban } \\
\text { difference in effects } \\
(1)\end{array}$} & \multicolumn{2}{|c|}{$\begin{array}{l}\text { Decomposition } 1 \\
\text { (urban loading) }\end{array}$} & \multicolumn{2}{|c|}{$\begin{array}{c}\text { Decomposition } 2 \\
\text { (nonurban loading) }\end{array}$} \\
\hline & & $\begin{array}{l}\text { Due to diffs } \\
\text { in } \\
\text { cov. levels } \\
(2)\end{array}$ & $\begin{array}{l}\text { Due to diffs } \\
\text { in cov. specific } \\
\text { effects } \\
(3)\end{array}$ & $\begin{array}{l}\text { Due to diffs } \\
\text { in } \\
\text { cov. levels } \\
(4)\end{array}$ & $\begin{array}{l}\text { Due to diffs } \\
\text { in cov. specific } \\
\text { effects } \\
(5)\end{array}$ \\
\hline Math & $\begin{array}{c}0.633 * * * \\
(0.079)\end{array}$ & $\begin{array}{l}0.322 * * * \\
(0.075)\end{array}$ & $\begin{array}{l}0.312 * * * \\
(0.094)\end{array}$ & $\begin{array}{c}0.250 \\
(0.163)\end{array}$ & $\begin{array}{c}0.383^{*} \\
(0.200)\end{array}$ \\
\hline $\mathrm{N}$ & 5,731 & & & & \\
\hline ELA & $\begin{array}{l}0.389 * * * \\
(0.073)\end{array}$ & $\begin{array}{l}0.184 * * \\
(0.077)\end{array}$ & $\begin{array}{l}0.205 * * \\
(0.095)\end{array}$ & $\begin{array}{c}0.197 \\
(0.146)\end{array}$ & $\begin{array}{c}0.192 \\
(0.180)\end{array}$ \\
\hline $\mathrm{N}$ & 5,734 & & & & \\
\hline
\end{tabular}

Notes: This table decomposes the difference between urban and nonurban charter treatment effects. Outcomes are test scores the year after the lottery. The treatment is a dummy for charter attendance. Column 1 shows the difference in urban and nonurban charter treatment effects, computed as described in the text. Columns 2 and 3 report the components of the urban/nonurban difference due to differences in covariate levels and differences in covariate-specific effects, weighting the difference in covariate means by the urban treatment effects. Columns 4 and 5 report a decomposition that weights the difference in means by the nonurban treatment effects. Covariates used in the decompositions are race (white versus nonwhite), sex, special education, free/reduced price lunch, and baseline score categories (advanced, proficient, needs improvement, warning) in math and ELA.

*** Significant at the 1 percent level.

** Significant at the 5 percent level.

* Significant at the 10 percent level.

column 3 shows that even with the same student mix found at nonurban charter schools, urban charters would be more effective than nonurban charters. The urban charter advantage can therefore be attributed to a combination of student demographics and larger treatment effects within demographic groups. As shown in columns 4 and 5, decomposition (9) produces qualitatively similar results, though the standard errors for this decomposition are much larger due to the relative imprecision of the estimated $\rho_{n}$.

\section{Differences in Schools}

Our exploration of school-level heterogeneity in achievement effects builds on observational estimates. This provides a larger sample of schools with more variation in characteristics and practices, and allows us to compare effects for eligible charter schools with and without lottery records. The observational estimates use a combination of matching and regression to control for observed differences between students attending different types of schools. Specifically, students attending lotteryeligible charters are matched to a control sample with the same baseline school, baseline year, sex, and race. Charter students are matched if they fall into a baseline school-year-sex-race cell that includes at least one regular public school student; likewise, regular public school students are matched if they fall into in a cell that includes at least one student in an eligible charter school. Every charter student in the matched sample is therefore compared to at least one demographically similar student from the same cohort and sending school. This procedure yields matches for 92 percent of students attending eligible charter schools. 
The observational analysis is based on the following estimating equation for student $i$ from matching cell $c$, observed in grade $g$ in year $t$ :

$$
y_{i g t c}=\alpha_{t}+\beta_{g}+\mu_{c}+X_{i}^{\prime} \theta+S_{i g t}^{\prime} \tau+\epsilon_{i g t c} .
$$

Here, $S_{i g t}$ is a vector measuring years spent in each eligible charter school for student $i$ from baseline through year $t$, while $X_{i}$ is a vector of additional student characteristics including limited English proficiency, special education status, subsidized lunch status, and baseline math and ELA scores. ${ }^{19}$ To validate the observational research design, we compared lottery-based and observational results for schools where both can be computed. This comparison was encouraging, as the two designs produced qualitatively similar estimates for most schools. The results of this validation exercise appear in online Appendix Table A5.20

We link charter school effectiveness to school practices using the following school-level regression:

$$
\hat{\tau}_{s}=\phi_{0}+\phi_{1} U_{s}+\phi_{2} L_{s}+\phi_{3} H_{s}+P_{s}^{\prime} \phi_{4}+u_{s}
$$

where $\hat{\tau}_{s}$ is an observational estimate of the effect of charter school $s$ from equation (11), $U_{s}$ is an urban dummy, $L_{s}$ is a lottery sample dummy, $H_{s}$ is a high school dummy, and $P_{s}$ is a vector of practices and characteristics. Observations in this regression are weighted by the reciprocal of the standard error of the estimated treatment effect. Standard errors are clustered at the school level to account for the fact that some schools contribute both middle and high school estimates to the sample. ${ }^{21}$

Consistent with the findings reported in Table 4, estimates of equation (12) reveal substantially larger treatment effects at urban charter schools. As shown in columns 1 and 5 of Table 8, the urban advantage is roughly $0.21 \sigma$ in math and $0.12 \sigma$ in ELA. Interestingly, oversubscribed schools with high-quality lottery records also seem to be more effective than nonlottery schools; lottery-sample schools generate gains that are $0.15 \sigma$ and $0.11 \sigma$ larger than the effects of nonlottery schools. This is further evidence of the importance of school-level heterogeneity in charter effects.

We next ask whether identification with the No Excuses instructional approach accounts for the urban charter advantage. Our focus on No Excuses is motivated by strong results for the schools in our study of Boston charters (Abdulkadiroğlu et al. 2011), most of which embrace No Excuses pedagogy, and by our results for a KIPP school in Lynn, Massachusetts (Angrist et al. 2010, 2012). KIPP is a rapidly growing charter management organization (CMO) whose schools are often seen as emblematic of the No Excuses approach. Moreover, in 2010 the Massachusetts

\footnotetext{
${ }^{19}$ These models also control for years spent in ineligible charters and alternative schools.

${ }^{20}$ Observational estimates for schools in the urban lottery sample are strikingly similar to the lottery results. The match between lottery and observational results for nonurban schools is not as good, with more positive observational estimates than those generated by lottery methods. This seems unlikely to affect the main conclusions from the observational analysis, however.

${ }^{21}$ The sample for equation (12) includes all eligible charter schools with data on at least one element of $P_{s}$. Dummies are included to indicate missing values for each survey question. The sample used to estimate equation (12) is larger than the sample of surveyed schools in Table 2 because some nonsurveyed schools contribute data on the traditional inputs included in $P_{s}$.
} 
Table 8-Observational Models for Charter Effectiveness

\begin{tabular}{|c|c|c|c|c|c|c|c|c|}
\hline & \multicolumn{4}{|c|}{ Math } & \multicolumn{4}{|c|}{ ELA } \\
\hline & (1) & (2) & (3) & (4) & (5) & (6) & (7) & (8) \\
\hline Urban & $\begin{array}{l}0.212 * * * \\
(0.049)\end{array}$ & $\begin{array}{c}0.078 \\
(0.063)\end{array}$ & $\begin{array}{c}-0.057 \\
(0.039)\end{array}$ & $\begin{array}{c}-0.008 \\
(0.058)\end{array}$ & $\begin{array}{l}0.123^{* * * *} \\
(0.032)\end{array}$ & $\begin{array}{c}0.034 \\
(0.026)\end{array}$ & $\begin{array}{c}-0.025 \\
(0.033)\end{array}$ & $\begin{array}{c}0.028 \\
(0.033)\end{array}$ \\
\hline Lottery & $\begin{array}{l}0.152^{* * *} \\
(0.070)\end{array}$ & $\begin{array}{c}0.041 \\
(0.055)\end{array}$ & $\begin{array}{c}-0.041 \\
(0.032)\end{array}$ & $\begin{array}{l}0.116^{* * *} \\
(0.053)\end{array}$ & $\begin{array}{l}0.105^{* * *} \\
(0.043)\end{array}$ & $\begin{array}{c}0.060 * \\
(0.033)\end{array}$ & $\begin{array}{c}0.024 \\
(0.045)\end{array}$ & $\begin{array}{c}0.069 \\
(0.046)\end{array}$ \\
\hline No Excuses & - & $\begin{array}{l}0.211 * * * \\
(0.076)\end{array}$ & $\begin{array}{c}-0.019 \\
(0.051)\end{array}$ & $\begin{array}{l}0.207 * * * \\
(0.060)\end{array}$ & - & $\begin{array}{l}0.150 * * * \\
(0.037)\end{array}$ & $\begin{array}{c}0.038 \\
(0.038)\end{array}$ & $\begin{array}{l}0.171 * * * \\
(0.051)\end{array}$ \\
\hline $\begin{array}{l}\text { Discipline and } \\
\text { comportment }\end{array}$ & - & - & $\begin{array}{l}0.293 * * * \\
(0.062)\end{array}$ & - & - & - & $\begin{array}{l}0.107 * * * \\
(0.041)\end{array}$ & - \\
\hline Uniforms & - & - & $\begin{array}{l}0.071 * * \\
(0.034)\end{array}$ & - & - & - & $\begin{array}{c}0.054 * \\
(0.028)\end{array}$ & - \\
\hline Cold-calling & - & - & $\begin{array}{l}0.130 * * * \\
(0.049)\end{array}$ & - & - & - & $\begin{array}{c}0.080 \\
(0.050)\end{array}$ & - \\
\hline $\begin{array}{l}\text { Strict adherence to } \\
\text { school-wide } \\
\text { standards }\end{array}$ & - & - & $\begin{array}{c}0.037 \\
(0.027)\end{array}$ & - & - & - & $\begin{array}{c}-0.014 \\
(0.033)\end{array}$ & - \\
\hline TFA alumni & - & - & $\begin{array}{c}0.018 \\
(0.047)\end{array}$ & - & - & - & $\begin{array}{c}0.021 \\
(0.055)\end{array}$ & - \\
\hline Minutes per day/60 & - & - & - & $\begin{array}{c}0.027 \\
(0.045)\end{array}$ & - & - & - & $\begin{array}{c}-0.003 \\
(0.022)\end{array}$ \\
\hline $\begin{array}{l}\text { Minutes in } \\
\text { subject/60 }\end{array}$ & - & - & - & $\begin{array}{c}0.131 \\
(0.097)\end{array}$ & - & - & - & $\begin{array}{c}0.008 \\
(0.051)\end{array}$ \\
\hline $\mathrm{PPE} / 1,000$ & - & - & - & $\begin{array}{c}-0.009 \\
(0.006)\end{array}$ & - & - & - & $\begin{array}{c}-0.009 \\
(0.009)\end{array}$ \\
\hline Observations & 33 & 33 & 33 & 33 & 33 & 33 & 33 & 33 \\
\hline
\end{tabular}

Notes: This table shows estimates from regressions of school-specific treatment effects on school characteristics. Regressions are weighted by the inverse of the relevant impact standard error. All models include a high school dummy and a dummy for middle schools with high school grades. Missing values are included in each regression. Standard errors are clustered at the school level.

*** Significant at the 1 percent level.

** Significant at the 5 percent level.

* Significant at the 10 percent level.

legislature passed a law relaxing the state's charter cap for districts in the lowest decile of MCAS performance, and many of the No Excuses schools from our earlier study (including KIPP, MATCH, Excel Academy, Edward Brooke, and Roxbury Preparatory) have responded to this with proposals for new campuses (Candal 2010).

No Excuses identification explains the relative effectiveness of urban charter schools in our sample. This can be seen in columns 2 and 6 of Table 8, which add a dummy for No Excuses to equation (12). ${ }^{22}$ No Excuses charter schools generate math and ELA gains that are $0.21 \sigma$ and $0.15 \sigma$ larger than the effects of other charters. Moreover, conditional on No Excuses status, the estimated urban coefficients are small and insignificant, while still precisely estimated. Since no nonurban charters identify with No Excuses, this implies that urban schools that do not identify with No

\footnotetext{
${ }^{22}$ The No Excuses dummy is constructed from responses to this question: Do you see your school as adhering to a particular approach or philosophy, such as No Excuses? We retained this measure from the less-detailed survey used in our earlier working paper (Angrist, Pathak, and Walters 2011) because of the potential for schools to strategically answer the No Excuses question in our new survey in response to our earlier results.
} 
Excuses also dramatically reduces the lottery coefficients, and renders lottery status statistically insignificant in math, though it remains marginally significant in ELA.

Figure 2 summarizes the relationship between No Excuses practice and charter impacts estimated using both observational and lottery-based methods. The lottery estimates come from a 2SLS regression that instruments time spent in each lotterysample charter with school-specific offers. ${ }^{23}$ The figure plots school-specific math coefficients against the corresponding ELA coefficients, labeling points by school type and location. The No Excuses advantage is striking: With few exceptions, estimates for urban No Excuses charters are large and positive in both subjects, while the estimates for nonurban schools as well as urban schools not associated with No Excuses are small or negative.

\section{A. Inside the No Excuses Black Box}

The results reported here suggest that the relative effectiveness of urban lottery charter schools is driven by these schools' embrace of the No Excuses instructional approach. We explore this finding further by using our survey results to get inside the "black box" of No Excuses effectiveness and ask which elements of the No Excuses model are most closely tied to charter impacts. Table 9 lists the full set of practices measured by the survey. As described in the online Survey Appendix, many survey questions ask respondents to report answers on a four- or five-point scale; we convert these to binary indicators equal to one for a top-of-scale response. Column 1 reports means, while columns 2, 4, and 6 show coefficients from regressions of No Excuses status, and observational estimates of charter effects on each practice variable and a high school dummy. Columns 3, 5, and 7 report $t$-statistics from these regressions.

No Excuses schools are more likely than other Massachusetts charters to emphasize discipline and comportment, college preparation, and traditional reading and math skills. This can be seen in estimates of the relationship between No Excuses status and measures of school philosophy, reported in the first two columns of panel A in Table 9. In addition, No Excuses schools are unlikely to emphasize social and physical well-being or cultural awareness. Panel B reports corresponding results for specific school practices. No Excuses schools are likely to use uniforms, to coldcall in the classroom, to use drills and extended instructional time in math, and to use formal reward systems to shape student behavior; they are unlikely to use group projects. As shown in panel $\mathrm{C}$, No Excuses charters also tend to hire TFA alumni and to videotape lessons to provide teachers with feedback. Moreover, columns 4-7 of Table 9 show that school characteristics highly correlated with No Excuses status also tend to be highly correlated with charter effectiveness.

Our findings here are consistent with results for effective New York charters reported by Dobbie and Fryer (2011b), who identify five practices that explain charter effectiveness. These are: high expectations, frequent teacher feedback, high-dosage tutoring, increased instructional time, and data-driven instruction. These practices

\footnotetext{
${ }^{23} \mathrm{We}$ also used these lottery estimates to estimate a version of equation 12 . The results were qualitatively similar to the observational estimates reported in Table 8, but the lottery-based analysis was much less precise because of the relative imprecision of school-specific lottery estimates.
} 
Panel A. Observational estimates

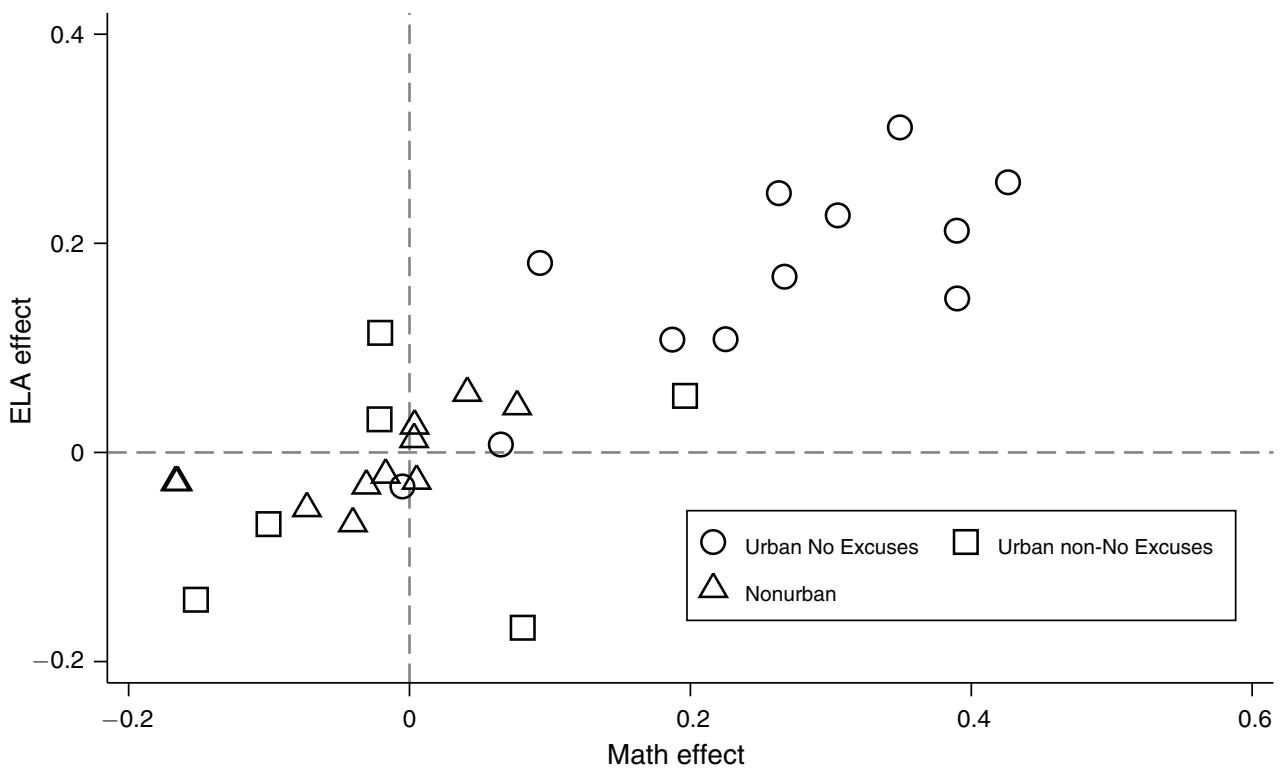

Panel B. Lottery estimates

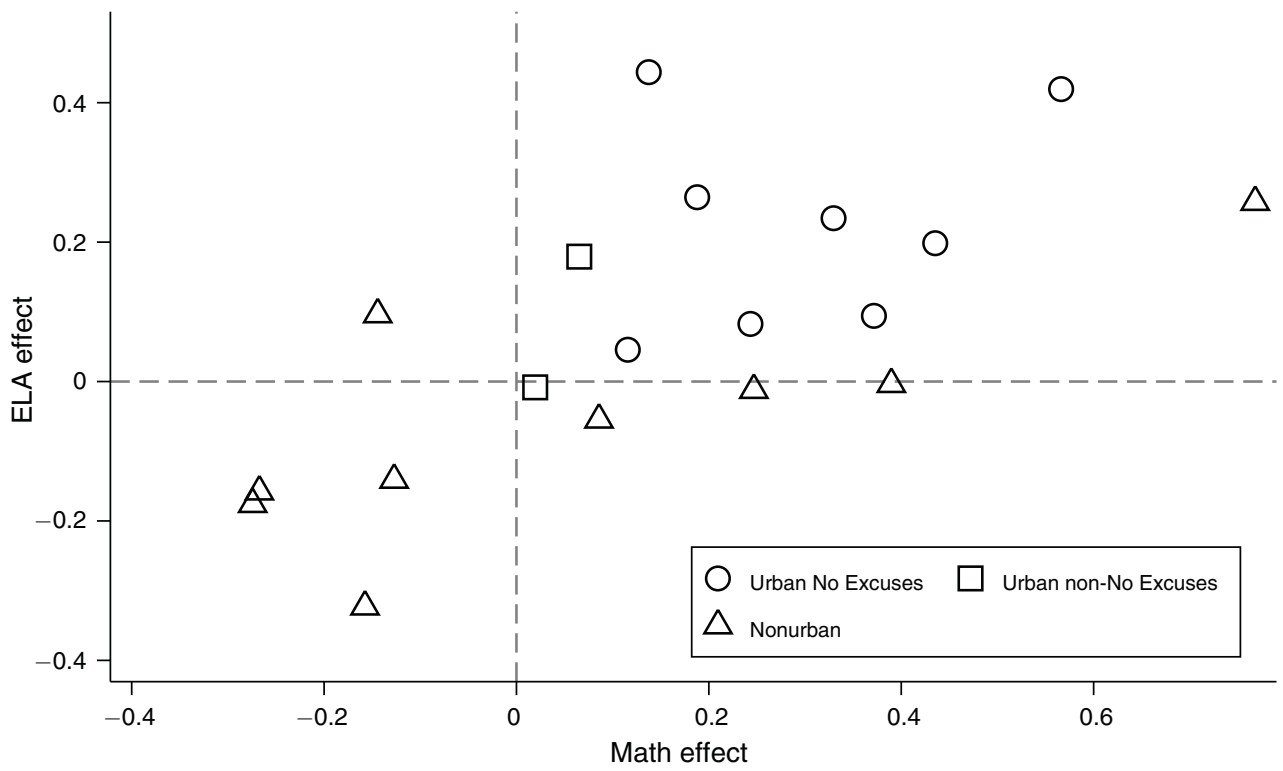

Figure 2. School-Specific Treatment EfFects

Notes: This figure plots school-specific math effects against school-specific ELA effects. The sample used to construct lottery estimates contains fewer schools than the observational sample. The figure plots both middle and high school estimates.

tend to be positively correlated with both No Excuses status and charter effectiveness in our sample. Our measure of discipline and comportment, one of the strongest correlates of No Excuses, is closely related to Dobbie and Fryer's measure of high 
Table 9-Correlates of No Excuses Identification and Charter School EfFectiveness

\begin{tabular}{|c|c|c|c|c|c|c|c|}
\hline \multirow[b]{2}{*}{ Characteristic } & \multirow[b]{2}{*}{$\begin{array}{c}\text { Mean } \\
(1)\end{array}$} & \multicolumn{2}{|c|}{ No Excuses } & \multicolumn{2}{|c|}{ Math effect } & \multicolumn{2}{|c|}{ ELA effect } \\
\hline & & $\begin{array}{l}\text { Coefficient } \\
\text { (2) }\end{array}$ & $\begin{array}{c}t \text {-stat } \\
(3)\end{array}$ & $\begin{array}{c}\text { Coefficient } \\
\text { (4) }\end{array}$ & $\begin{array}{l}t \text {-stat } \\
(5)\end{array}$ & $\begin{array}{c}\text { Coefficient } \\
\text { (6) }\end{array}$ & $\begin{array}{l}t \text {-stat } \\
(7)\end{array}$ \\
\hline \multicolumn{8}{|l|}{ Panel A. School philosophy } \\
\hline No Excuses & 0.364 & 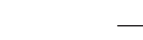 & & 0.247 & 4.810 & 0.145 & 3.692 \\
\hline Discipline and comportment & 0.391 & 0.660 & 4.126 & 0.297 & 5.944 & 0.175 & 4.097 \\
\hline $\begin{array}{l}\text { Strict adherence to school-wide } \\
\text { standards }\end{array}$ & 0.565 & 0.569 & 3.218 & 0.236 & 3.672 & 0.096 & 1.790 \\
\hline College preparation & 0.783 & 0.545 & 2.219 & 0.272 & 3.180 & 0.129 & 1.927 \\
\hline $\begin{array}{l}\text { Traditional reading and } \\
\text { math skills }\end{array}$ & 0.565 & 0.386 & 1.929 & 0.182 & 2.516 & 0.039 & 0.679 \\
\hline $\begin{array}{l}\text { Measurable results } \\
\text { (achievement gains) }\end{array}$ & 0.522 & 0.159 & 0.718 & 0.192 & 2.600 & 0.075 & 1.304 \\
\hline Common core values & 0.500 & 0.114 & 0.513 & -0.047 & -0.531 & -0.103 & -1.812 \\
\hline Individually-tailored instruction & 0.261 & 0.016 & 0.067 & 0.005 & 0.059 & -0.017 & -0.261 \\
\hline STEM & 0.682 & -0.166 & -0.710 & 0.028 & 0.341 & 0.047 & 0.799 \\
\hline $\begin{array}{l}\text { Speech and writing } \\
\text { development }\end{array}$ & 0.478 & -0.200 & -0.961 & -0.018 & -0.222 & -0.010 & -0.175 \\
\hline Qualitative achievement & 0.348 & -0.279 & -1.248 & -0.019 & -0.214 & -0.034 & -0.554 \\
\hline Leadership & 0.087 & -0.429 & -1.150 & -0.077 & -0.527 & -0.173 & -1.826 \\
\hline Cultural awareness & 0.304 & -0.473 & -2.310 & -0.123 & -1.463 & -0.137 & -2.560 \\
\hline Social and physical well-being & 0.565 & -0.474 & -2.480 & -0.127 & -1.611 & -0.103 & -1.935 \\
\hline \multicolumn{8}{|l|}{ Panel B. School practices } \\
\hline Uniforms & 0.708 & 0.644 & 3.643 & 0.225 & 3.227 & 0.091 & 1.623 \\
\hline Cold calling & 0.273 & 0.654 & 3.590 & 0.218 & 2.701 & 0.121 & 2.023 \\
\hline Math drills & 0.391 & 0.549 & 3.014 & 0.252 & 4.048 & 0.106 & 1.973 \\
\hline Extended math instruction & 0.273 & 0.537 & 2.639 & 0.257 & 3.377 & 0.121 & 2.009 \\
\hline Reward system & 0.682 & 0.510 & 2.492 & 0.164 & 1.968 & 0.048 & 0.831 \\
\hline $\begin{array}{l}\text { Informal tests to gauge } \\
\text { understanding }\end{array}$ & 0.696 & 0.473 & 2.310 & 0.189 & 2.446 & 0.037 & 0.612 \\
\hline College icons in the classroom & 0.522 & 0.439 & 2.309 & 0.225 & 3.494 & 0.070 & 1.282 \\
\hline Emphasis on MCAS & 0.591 & 0.432 & 2.120 & 0.244 & 3.634 & 0.144 & 2.802 \\
\hline Tutoring for all students & 0.348 & 0.385 & 1.858 & 0.201 & 2.762 & 0.096 & 1.719 \\
\hline Days in school year $>$ median & 0.435 & 0.346 & 1.703 & 0.094 & 1.170 & 0.055 & 0.972 \\
\hline $\begin{array}{l}\text { Minutes in school } \\
\text { day }>\text { median }\end{array}$ & 0.348 & 0.346 & 1.581 & 0.192 & 2.469 & 0.040 & 0.658 \\
\hline Student contract & 0.696 & 0.348 & 1.577 & 0.132 & 1.554 & 0.014 & 0.219 \\
\hline DEAR or SSR & 0.391 & 0.294 & 1.417 & -0.003 & -0.033 & -0.034 & -0.590 \\
\hline Parent contract & 0.696 & 0.268 & 1.203 & 0.107 & 1.255 & 0.047 & 0.776 \\
\hline Extended reading instruction & 0.190 & 0.299 & 1.120 & 0.280 & 3.033 & 0.139 & 1.952 \\
\hline $\begin{array}{l}\text { Response to intervention } \\
\text { for math }\end{array}$ & 0.182 & 0.244 & 0.860 & 0.213 & 2.132 & 0.142 & 2.012 \\
\hline Reading aloud & 0.217 & 0.204 & 0.799 & 0.014 & 0.142 & -0.005 & -0.065 \\
\hline $\begin{array}{l}\text { Response to intervention } \\
\text { for reading }\end{array}$ & 0.227 & 0.097 & 0.370 & 0.199 & 2.210 & 0.115 & 1.757 \\
\hline Teacher autonomy & 0.524 & -0.194 & -0.887 & -0.149 & -1.868 & -0.093 & -1.675 \\
\hline Group projects & 0.435 & -0.490 & -2.663 & -0.211 & -3.146 & -0.121 & -2.400 \\
\hline
\end{tabular}

(Continued)

expectations. ${ }^{24}$ Table 9 also shows that No Excuses charters are more likely than other charters to observe teachers in the classroom and to use video for feedback, to have tutoring programs for all students, and to have run long days and extended school years. They also tend to use tests to gauge understanding, suggesting a data-driven approach.

\footnotetext{
${ }^{24}$ Dobbie and Fryer's expectations variable combines questions measuring "very high expectations for student behavior and discipline" and "a relentless focus on academic goals and having students meet them."
} 
Table 9-Correlates of No Excuses Identification and Charter School Effectiveness (Continued)

\begin{tabular}{|c|c|c|c|c|c|c|c|}
\hline \multirow[b]{2}{*}{ Characteristic } & \multirow[b]{2}{*}{$\begin{array}{c}\text { Mean } \\
(1)\end{array}$} & \multicolumn{2}{|c|}{ No Excuses } & \multicolumn{2}{|c|}{ Math effect } & \multicolumn{2}{|c|}{ ELA effect } \\
\hline & & $\begin{array}{c}\text { Coefficient } \\
(2) \\
\end{array}$ & $\begin{array}{c}t \text {-stat } \\
(3)\end{array}$ & $\begin{array}{c}\text { Coefficient } \\
(4)\end{array}$ & $\begin{array}{c}t \text {-stat } \\
(5)\end{array}$ & $\begin{array}{c}\text { Coefficient } \\
(6)\end{array}$ & $\begin{array}{c}t \text {-stat } \\
(7) \\
\end{array}$ \\
\hline \multicolumn{8}{|l|}{ Panel C. Teacher profile } \\
\hline TFA alumni & 0.261 & 0.691 & 3.062 & 0.202 & 2.145 & 0.118 & 1.736 \\
\hline Lessons videotaped & 0.565 & 0.490 & 2.663 & 0.201 & 2.940 & 0.113 & 2.201 \\
\hline MATCH teacher residency & 0.143 & 0.545 & 1.877 & 0.244 & 2.383 & 0.138 & 1.821 \\
\hline At-will hiring & 0.304 & 0.349 & 1.606 & 0.056 & 0.647 & 0.040 & 0.654 \\
\hline TFA novices & 0.174 & 0.352 & 1.309 & 0.068 & 0.643 & 0.020 & 0.262 \\
\hline $\begin{array}{l}\text { Observations on new teachers } \\
\text { per month }\end{array}$ & 1.717 & 0.122 & 1.022 & 0.053 & 1.169 & 0.029 & 0.908 \\
\hline $\begin{array}{l}\text { Observations on veteran } \\
\text { teachers per month }\end{array}$ & 1.293 & 0.077 & 0.586 & 0.041 & 0.815 & 0.002 & 0.066 \\
\hline Recent college graduates & 0.136 & -0.323 & -1.017 & -0.127 & -1.036 & -0.131 & -1.607 \\
\hline Observations & & \multicolumn{2}{|c|}{27} & \multicolumn{2}{|c|}{27} & \multicolumn{2}{|c|}{27} \\
\hline
\end{tabular}

Notes: This table reports coefficients from regressions of a No Excuses dummy and school-specific observational estimates of treatment effects on a high school dummy and school practices (one regression per practice). Within each panel, characteristics are sorted by strength of relationship with No Excuses identification. The survey questions appear in the online survey Appendix.

The five variables most correlated with No Excuses status as measured by their $t$-statistics are emphasis on discipline, school uniforms, cold-calling, strict adherence to school-wide standards, and the use of TFA alumni. To ask which practices best explain the effectiveness of No Excuses charters, we next add these five variables to equation (12). Columns 3 and 7 of Table 8 show that, of these five, the variables measuring discipline and school uniforms are most predictive of charter impacts. Schools that emphasize discipline and comportment raise achievement in math and ELA by $0.29 \sigma$ and $0.11 \sigma$ more than schools that do not. The use of uniforms is associated with increased effectiveness of $0.07 \sigma$ and $0.05 \sigma$. With the inclusion of these practice variables, the No Excuses coefficient becomes small and statistically insignificant for both subjects. After controlling for key elements of the No Excuses model the No Excuses coefficient is hard to interpret. No Excuses practices are typically implemented as a package rather than in isolation, and the five practices included in Table 8 are likely correlated with other unmeasured features of No Excuses. For example, it seems unlikely that the use of uniforms alone raises test scores. The results in Table 8 suggest that schools embracing key elements of the No Excuses package, in particular strict discipline, uniforms, and cold-calling, are especially effective.

Finally, we ask whether more traditional school inputs-including instruction time, which is correlated with No Excuses status (see panel B of Table 9) — play a role in the No Excuses advantage. Columns 4 and 8 in Table 8 show the results of substituting instruction time (minutes per day and in the relevant subject) and perpupil expenditures for measures of No Excuses practice in equation (12). These variables are often thought to be part of the education production function. ${ }^{25}$ As

\footnotetext{
${ }^{25}$ Motivated in part by the long days at successful charter schools, the Massachusetts legislature recently authorized a pilot program to extend the school day by two hours in some traditional public schools (Pennington 2007).
} 
it turns out, however, these traditional inputs are unrelated to variation in charter school treatment effects and do little to account for the No Excuses advantage.

Our results suggest that No Excuses practices are a key driver of charter school effectiveness, and that discipline may be an especially important contributor. We might therefore expect to see a marked impact on disciplinary outcomes in urban charter schools. We used a 2SLS strategy paralleling our achievement analysis to investigate the effects of charter attendance on suspensions, truancy, and total days attended. This analysis revealed large effects of urban charters on discipline and attendance. Specifically, urban charter attendance is estimated to increase suspensions by 0.7 days in middle school and more than a full day in high school, effects that exceed mean suspension rates in the lottery sample (the full set of discipline results is reported in online Appendix Table A6). Estimates for both middle and high school show significant increases in out-of-school suspensions, and smaller (but still substantial) increases in in-school suspensions. In contrast, estimates for nonurban charter schools show little effect on discipline. ${ }^{26}$ These results sharpen the distinction between urban and nonurban charters. Attendance at urban No Excuses charter schools produces large effects on discipline as well as achievement; attendance at other charter schools has little effect in either domain.

\section{Conclusions}

Massachusetts' urban charter schools generate impressive achievement gains, while nonurban charters are largely ineffective and appear to reduce achievement for some. Candidate explanations for this constellation of findings include the fact that urban charter schools serve larger shares of minority students in districts where the surrounding achievement level is generally low, keep their students in school longer, spend more money per pupil, and are much more likely to identify with the No Excuses instructional approach than are nonurban schools. Our analysis examines the contribution of these student- and school-level factors to the urban charter advantage.

Massachusetts' urban charter schools, including the oversubscribed schools at the heart of our lottery analysis, serve a typical urban population characterized by low test scores and high poverty rates. On average, urban charters push their students well beyond the achievement levels characteristic of urban public school districts, while nonurban charter schools leave their students' achievement unchanged or diminished from a higher starting point. Urban charter schools are most effective for minorities, poor students, and low baseline achievers, so part of the urban charter advantage can be explained by student demographics. On the other hand, nonurban charter schools fail to show clear gains for any group; the urban advantage would likely remain were nonurban students more like those found in cities. Our analysis also reveals important heterogeneity within the set of urban schools. Over-subscribed schools with well-documented admissions processes are more effective than other urban charters.

Per-pupil expenditure is of longstanding interest to researchers and policymakers; increasing per-pupil expenditure is sometimes seen as an alternative to structural reforms (Hanushek 1997).

${ }^{26}$ Both urban and nonurban charters appear to increase days of attendance, though estimates here are smaller for nonurban charters. 
Our analysis of the relationship between school characteristics and treatment effects suggests that adherence to the No Excuses paradigm can account for both the urban and lottery-sample charter advantages. To get inside the black box of No Excuses, we collected data on school practices. No Excuses schools are more likely to use strict discipline and require uniforms, to cold-call in the classroom, and to hire alumni of the Teach for America program. Consistent with a No Excuses explanation of the urban charter advantage, the large achievement gains generated by urban charter schools are mirrored by substantial effects on disciplinary outcomes in the urban sample.

Our negative estimates for nonurban charter middle schools raise the question of why, despite their unimpressive achievement effects, many of these schools are oversubscribed. One possibility is that parents misjudge the consequences of nonurban charter attendance. In a study of school choice, Rothstein (2006) argues that parental choice is driven primarily by levels of peer achievement rather than school effectiveness. Of course, nonurban charter schools may generate gains on dimensions that nonurban families value more than the skills measured by the MCAS, especially in view of the fact that most nonurban students do reasonably well in any case. Still, it seems unlikely that most nonurban parents would welcome a deterioration in basic skills. In ongoing work, we're studying other outcomes in an effort to determine whether the heterogeneous findings for achievement reported here have longer term consequences. Preliminary results show positive effects of Boston's charter high schools on SAT scores and four-year college attendance, suggesting that the effects of urban charter attendance are persistant (Angrist et al. 2013).

Finally, it's worth noting that the charter school effect heterogeneity documented here is relevant to the ongoing debate over charter expansion in Massachusetts and elsewhere. Many states cap the number of charter schools, and the US Department of Education is pressing states to lift these caps. The 2010 law relaxing Massachusetts' cap gives priority to "proven providers" who have previously operated schools deemed to be successful (Candal 2010). Our methods show how a distinction between effective and ineffective charters can be grounded in rigorous empirical analysis, while our results suggest that charter expansion policies favoring operators and pedagogical models with documented effectiveness increase the likelihood that charters will reduce achievement gaps.

\section{REFERENCES}

Abadie, Alberto. 2002. "Bootstrap Tests for Distributional Treatment Effects in Instrumental Variable Models." Journal of the American Statistical Association 97 (457): 284-92.

Abadie, Alberto. 2003. "Semiparametric instrumental variable estimation of treatment response models." Journal of Econometrics 113 (2): 231-63.

Abdulkadiroglu, Atila, Joshua Angrist, Sarah Cohodes, Susan Dynarski, Jon Fullerton, Thomas Kane, and Parag Pathak. 2009. Informing the Debate: Comparing Boston's Charter, Pilot, and Traditional Schools. The Boston Foundation (TBF). Boston, January.

Abdulkadiroğlu, Atila, Joshua D. Angrist, Susan M. Dynarski, Thomas J. Kane, and Parag A. Pathak. 2011. "Accountability and Flexibility in Public Schools: Evidence from Boston's Charters and Pilots." Quarterly Journal of Economics 126 (2): 699-748.

-Altonji, Joseph G., Todd E. Elder, and Christopher R. Taber. 2005. "Selection on Observed and Unobserved Variables: Assessing the Effectiveness of Catholic Schools." Journal of Political Economy 113 (1): 151-84. 
Angrist, Joshua D., Sarah R. Cohodes, Susan M. Dynarski, Parag Pathak, and Christopher Walters. 2013 'Stand and Deliver: Effects of Boston's Charter High Schools on College Preparation, Entry, and Choice." National Bureau of Economic Research (NBER) Working Paper 19275.

Angrist, Joshua D., Susan M. Dynarski, Thomas J. Kane, Parag A. Pathak, and Christopher R. Walters. 2010. "Inputs and Impacts in Charter Schools: KIPP Lynn.” American Economic Review 100 (2): 239-43.

Angrist, Joshua D., Susan M. Dynarski, Thomas J. Kane, Parag A. Pathak, and Christopher R. Walters. 2012. "Who Benefits from KIPP?" Journal of Policy Analysis and Management 31 (4): 837-60.

-Angrist, Joshua D., and Guido Imbens. 1995. "Two-Stage Least Squares Estimation of Average Causal Effects in Models with Variable Treatment Intensity." Journal of the American Statistical Association 90 (430): 431-42.

Angrist, Joshua D., Parag A. Pathak, and Christopher R. Walters. 2011. "Explaining Charter School Effectiveness." National Bureau of Economic Research (NBER) Working Paper 17332.

-Angrist, Joshua D., Parag A. Pathak, and Christopher R. Walters. 2013. "Explaining Charter School Effectiveness: Dataset." American Economic Journal: Applied Economics http://dx.doi. org/10.1257/app.5.4.1.

Blinder, Alan S. 1973. "Wage Discrimination: Reduced Form And Structural Variables." Journal of Human Resources 8 (4): 436-55.

Cameron, A. Colin, Jonah B. Gelbach, and Douglas L. Miller. 2008. "Bootstrap-Based Improvements for Inference with Clustered Errors." Review of Economics and Statistics 90 (3): 414-27.

Candal, Cara Stillings. 2010. "Charter School Caps and Strings Attached: The Achievement Gap Act of 2010 and Charter Policy." Pioneer Institute White Paper 68.

Carter, Samuel Casey. 2000. No Excuses: Lessons from 21 High-Performing, High-Poverty Schools. Washington, DC: Heritage Foundation.

Curto, Vilsa E., and Roland G. Fryer, Jr. 2011. "Estimating the Returns to Urban Boarding Schools: Evidence from SEED.” National Bureau of Economic Research (NBER) Working Paper 16746.

Dobbie, Will, and Roland G. Fryer, Jr. 2011a. "Are High-Quality Schools Enough to Increase Achievement Among the Poor? Evidence from the Harlem Children's Zone." American Economic Journal: Applied Economics 3 (3): 158-87.

Dobbie, Will, and Roland G. Fryer, Jr. 2011b. "Getting Beneath the Veil of Effective Schools: Evidence from New York City.” National Bureau of Economic Research (NBER) Working Paper 17632.

-Evans, William N., and Robert M. Schwab. 1995. "Finishing High School and Starting College: Do Catholic Schools Make a Difference?” Quarterly Journal of Economics 110 (4): 941-74.

Fryer, Roland G., Jr. 2011. "Injecting Successful Charter School Strategies into Traditional Public Schools: Early Results from an Experiment in Houston." National Bureau of Economic Research (NBER) Working Paper 17494.

Gleason, Philip, Melissa Clark, Christina Tuttle, and Emily Dwoyer. 2010. The Evaluation of Charter School Impacts: Final Report. U.S. Department of Education National Center for Education Evaluation and Regional Assistance (NCEE) 2010-4029. Washington, DC, June.

Grogger, Jeffrey, and Derek Neal. 2000. "Further Evidence on the Effects of Catholic Secondary Schooling." Brookings-Wharton Papers on Urban Affairs 1 (1): 151-93.

Hanushek, Eric A. 1997. "Assessing the Effects of School Resources on Student Performance: An Update.” Educational Evaluation and Policy Analysis 19 (2): 141-64.

Hoxby, Caroline. 2004. "Achievement in Charter Schools and Regular Public Schools in the United States: Understanding the Differences." http://www.vanderbilt.edu/schoolchoice/downloads/ papers/hoxby2004.pdf.

Hoxby, Caroline, Sonali Murarka, and Jennie Kang. 2009. How New York City's Charter Schools Affect Achievement. New York City Charter Schools Evaluation Project. Cambridge, MA, February.

Hoxby, Caroline, and Jonah Rockoff. 2004. "The Impact of Charter Schools on Student Achievement." Unpublished.

Hu, Winnie. 2011. "Charter School Battle Shifts to Affluent Suburbs.” New York Times, July 16, A1. Print.

- Imbens, Guido W., and Joshua D. Angrist. 1994. "Identification And Estimation Of Local Average Treatment Effects." Econometrica 62 (2): 467-75.

Imberman, Scott A. 2011. "Achievement and Behavior in Charter Schools: Drawing a More Complete Picture." Review of Economics and Statistics 93 (2): 416-35.

Lake, Robin, Melissa Bowen, Allison Demeritt, Moira McCullough, Joshua Haimson, and Brian Gill. 2012. Learning from Charter School Management Organizations: Strategies for Student Behavior and Teacher Coaching. Center on Reinventing Public Education (CRPE). Seattle, March.

Neal, Derek. 1997. "The Effects of Catholic Secondary Schooling on Educational Achievement." Journal of Labor Economics 15 (1): 98-123. 
-Oaxaca, Ronald. 1973. "Male-Female Wage Differentials in Urban Labor Markets." International Economic Review 14 (3): 693-709.

Pennington, Hilary C. 2007. The Massachusetts Expanding Learning Time to Support Student Success Initiative. Center for American Progress (CAP). Washington, DC, January.

- Rothstein, Jesse. 2006. "Good Principals or Good Peers? Parental Valuation of School Characteristics, Tiebout Equilibrium, and the Incentive Effects of Competition among Jurisdictions." American Economic Review 96 (4): 1333-50.

Rothstein, Richard. 2004. Class and Schools: Using Social, Economic, and Educational Reform to Close the Black-White Achievement Gap. Washington, DC: Economic Policy Institute.

Thernstrom, Abigail, and Stephen Thernstrom. 2003. No Excuses: Closing the Racial Gap in Learning. New York: Simon and Schuster.

Zimmer, Ron, Brian Gill, Kevin Booker, Stephanne Lavertu, Tim Sass, and John Witte. 2009. Charter Schools in Eight States: Effects on Achievement, Attainment, Integration and Competition. RAND Corporation. Santa Monica, CA. 
This article has been cited by:

1. David J. Deming. 2014. Using School Choice Lotteries to Test Measures of School Effectiveness. American Economic Review 104:5, 406-411. [Abstract] [View PDF article] [PDF with links]

2. David J. Deming, Justine S. Hastings, Thomas J. Kane, Douglas O. Staiger. 2014. School Choice, School Quality, and Postsecondary Attainment†. American Economic Review 104:3, 991-1013. [Abstract] [View PDF article] [PDF with links] 